\title{
Solubility of Pt in sulphide mattes: Implications for the genesis of PGE-rich horizons in layered intrusions
}

\author{
Raúl O.C. Fonseca ${ }^{\text {a,b,* }}$, Ian H. Campbell ${ }^{\text {a }}$, Hugh St. C. O’Neill ${ }^{\text {a }}$, Charlotte M. Allen ${ }^{\text {a }}$ \\ ${ }^{a}$ Research School of Earth Sciences, Australian National University, Canberra, ACT, Australia \\ ${ }^{\mathrm{b}}$ Steinmann Institut, Universität Bonn, Bonn, Germany
}

Received 15 October 2008; accepted in revised form 23 June 2009; available online 19 July 2009

\begin{abstract}
The partitioning of $\mathrm{Pt}$ in sulphide melt (matte) has been studied as a function of $f \mathrm{~S}_{2}$ and $f \mathrm{O}_{2}$ at 1200 and $1300{ }^{\circ} \mathrm{C}$. The results show that the solubility of $\mathrm{Pt}$ in mattes increases strongly with increasing $f \mathrm{~S}_{2}$ and decreases weakly with increasing $f \mathrm{O}_{2}$. The increase in $\mathrm{Pt}$ solubility with increasing $f \mathrm{~S}_{2}$ is attributed to $\mathrm{Pt}$ dissolving in the melt as a sulphide species and the weak inverse dependence of Pt solubility on $f \mathrm{O}_{2}$ to the diluting effect of increasing $\mathrm{O}$ in the melt at high $f \mathrm{O}_{2}$. These results, coupled with measurements of Pt solubility in silicate melts taken from the literature, allow the calculation of Pt matte/silicate-melt partition coefficients ( $D_{\mathrm{Pt}}^{\text {matte-sil }}$ ) for a range of conditions pertinent to the formation of Pt-rich horizons in layered intrusions. The calculated values range between $10^{7}$ and $10^{11}$, depending on $f \mathrm{O}_{2}$ and $f \mathrm{~S}_{2}$, several orders of magnitude higher than previously published values. Our preferred value for $D_{\mathrm{Pt}}^{\text {matte-sil }}$ for conditions appropriate to the Merensky Reef is $10^{7}$ and for the Stillwater Pt-rich horizon $10^{8}$. The new results are consistent with the magmatic hypothesis for Pt-rich horizons in layered intrusions.
\end{abstract}

(c) 2009 Elsevier Ltd. All rights reserved.

\section{INTRODUCTION}

Platinum Group Elements (Os, Ir, Ru, Pt, Pd and Rh the PGE) have a high affinity for metallic and sulphide phases and as a consequence are defined as being both chalcophile and highly siderophile elements. The highly siderophile characteristics of $\mathrm{Pt}$ are well accepted, with measured distribution coefficients $\left(D_{\mathrm{Pt}}^{\text {metal-sil }}\right)$ as high as $10^{12}$ for the partitioning of Pt between metal and silicate melt. However, the extent to which $\mathrm{Pt}$ is chalcophile remains controversial, with measured partitioning coefficients for $\mathrm{Pt}$ between sulphide melt (here referred to as matte) and silicate melt $\left(D_{\mathrm{Pt}}^{\text {matte-sil }}\right)$ ranging between $10^{3}$ and $10^{9}$. Many authors including Helz and Rait (1988), Peach et al. (1990, 1994), Stone et al. (1990), Fleet et al. (1991, 1996),

\footnotetext{
${ }^{*}$ Corresponding author. Address: Steinmann Institut, Universität Bonn, Bonn, Germany. Tel.: +49 (0)228 739782; fax: +49 (0)228 732763 .

E-mail address: raul.fonseca@uni-bonn.de (R.O.C. Fonseca).
}

Bezmen et al. (1994), Crocket et al. (1997), and Fleet et al. (1999) accept values towards the lower end of this range $\left(10^{3}-10^{4}\right)$. However, others (e.g., Bezmen et al., 1991; Pruseth and Palme, 2004) have calculated $D_{\mathrm{Pt}}^{\text {matte-sil }}$ that are several orders of magnitude higher than these previous values (Table 1$)$.

The controversy regarding the extent to which Pt is chalcophile affects whether the so-called " $R$-factor" model can explain PGE enrichment in magmatic sulphide deposits (e.g., Campbell and Naldrett, 1979). If $D_{\mathrm{Pt}}^{\text {matte-sil }}$ is very large, the high-temperature equilibration between a matte and a silicate melt will inexorably lead to the matte being enriched in $\mathrm{Pt}$ when compared to the silicate melt. Furthermore, the enrichment would not only be a function of the high $D_{\mathrm{Pt}}^{\text {matte-sil }}$ but, due to mass balance considerations, would also be constrained by the mass ratio of the silicate liquid to sulphide liquid, $R$. The $R$-factor model, which was initially proposed by Campbell and Naldrett (1979), has been used to explain the high PGE enrichments observed in horizons found in a number of mafic layered intrusions such as the Merensky Reef, Stillwater complex, etc. (e.g., Keays 
Table 1

Summary of some of the different matte/silicate and metal silicate partition coefficients for Pt and Pd available in the literature.

\begin{tabular}{lllllll}
\hline Authors & Temperature $\left({ }^{\circ} \mathrm{C}\right)$ & Pressure (bars) & $-\log f S_{2}$ & $-\log f O_{2}$ & $D_{\mathrm{Pt}}^{\text {matte-sil }}$ & $D_{\mathrm{Pd}}^{\text {matte-sil }}$ \\
\hline Bezmen et al. (1991) & $1200-1350$ & $100-4000$ & $0.1-3.7$ & $9.9-12.4$ & $>106$ & - \\
Bezmen et al. (1994) & $1200-1300$ & $1000-4000$ & $0.3-4$ & $9.9-12$ & - & $5.5 \times 10^{4}$ \\
Crocket et al. (1997) & 1250 & 1 & 0.9 & 8.6 & $-65 \times 10^{4}$ & $2.8 \times 10^{4}$ \\
Fleet et al. (1991) & 1300 & 1 & - & $\mathrm{CCO}^{\mathrm{a}}-\mathrm{WM}^{\mathrm{b}}$ & $2.00 \times 10^{4}$ & $2.00 \times 10^{4}$ \\
Fleet et al. (1996) & 1250 & 1 & $0.9-1.0$ & $8.5-8.6$ & $1.50 \times 10^{4}$ & - \\
Fleet et al. (1999) & 1300 & 1 & $0.2-2.3$ & $11.4-12$ & $1.30 \times 10^{4}$ & $2.50 \times 10^{4}$ \\
Helz and Rait (1988) & - & - & - & - & $3.6 \times 10^{4}$ & $2.50 \times 10^{4}$ \\
Peach et al. (1990) & 1260 & 1 & - & QFM $^{-0.5}$ & $1 \times 10^{3}$ & $2.30 \times 10^{4}$ \\
Peach et al. (1994) & 1450 & 1 & $2.3-1$ & $\sim \mathrm{QFM}^{2.5}$ & - & $3.4 \times 10^{4}$ \\
Pruseth and Palme (2004) & $1100-1300$ & 1 & $0-6$ & $\mathrm{QFM}^{\mathrm{c}}$ (assumed) & $>10^{9}$ & - \\
Stone et al. (1990) & 1200 & & 0.9 & 9.2 & $9.1 \times 10^{3}$ & $8.80 \times 10^{4}$ \\
\hline
\end{tabular}

${ }^{\text {a }} \mathrm{C}-\mathrm{CO}-\mathrm{CO}_{2}$ oxygen fugacity buffer.

${ }^{\mathrm{b}}$ Wustite-magnetite oxygen fugacity buffer.

${ }^{c}$ Quartz-fayalite-magnetite oxygen fugacity buffer. Taken from Mallmann and O'Neill (2007).

and Campbell, 1981; Campbell et al., 1983; Campbell and Barnes, 1984; Barnes and Naldrett, 1985; Naldrett et al., 1987; Barnes and Campbell, 1988; Godel et al., 2007). However, the $R$-factor model was almost immediately criticized, because until recently, $D_{\mathrm{Pt}}^{\text {matte-sil }}$ available in the literature (e.g., Helz and Rait, 1988; Peach et al., 1990, 1994; Stone et al., 1990; Fleet et al., 1991, 1996, 1999; Bezmen et al., 1994; Crocket et al., 1997) were lower than required by the model to explain the level of PGE enrichment in sulphides observed in many magmatic PGE deposits. Fleet et al. (1999) for example, argued that the low $D_{\mathrm{PGE}}^{\text {matte-sil }}$ values measured in their experiments, and also those measured by Peach et al. (1994), were not consistent with the enrichments observed in the reef deposits of the Bushveld and Stillwater complexes. Fleet et al. (1999) instead proposed that the discrepancy between measured $D_{\mathrm{PGE}}^{\text {matte-sil }}$ and the empirically determined $D_{\mathrm{PGE}}^{\text {matte-sil }}$ argued in favor of an "upward" migrating fluid as the source of PGE enrichment. This view was reiterated by Mathez (1995) who pointed out that because PGE enrichments in mafic layered intrusions are often associated with textural indicators for extensive metasomatism, "it may be taken as evidence that the PGE were enriched by a metasomatic process", a view that found support in a number of subsequent studies (Ballhaus and Stumpfl, 1985, 1986; Boudreau and McCallum, 1992; Boudreau and Meurer, 1999; Meurer et al., 1997; Meurer and Boudreau, 1998). However, Wood (1987) pointed out that even though PGE may be transported in Cl-rich brine fluids, as suggested for instance by Boudreau and McCallum (1992) and Boudreau and Meurer (1999), Cu, Ni and Fe should be more enriched by hydrothermal fluids than the PGE by "several factors of tens", which is not observed in the PGE-rich reefs of the Stillwater and Bushveld Complexes. Moreover, PGE abundances in hydrothermal sulphides are typically very low as shown in a recent study by Luguet et al. (2004), further reinforcing the likelihood that PGE cannot be strongly enriched by hydrothermal fluids. A more detailed discussion on the pros and cons of the "upward" migrating fluid model may be found on Barnes and Campbell (1988).

The discrepancies between estimates for $D_{\mathrm{PtGE}}^{\text {matte-sil }}$ are at the core of the debate between the "upper", those who advocate a hydrothermal origin of PGE-rich reefs, and the "downers", who favor a magmatic origin. The direct experimental determination of Pt (or PGE) matte/silicatemelt partition coefficients $\left(D_{\mathrm{Pt}}^{\text {matte-sil }}\right)$ is difficult (e.g., O'Neill et al., 1995). Although there are numerous experimental data on the partitioning of $\mathrm{Pt}$ between mattes and silicate melts (Bezmen et al., 1991, 1994; Crocket et al., 1997; Fleet and Stone, 1991; Fleet et al., 1996, 1999; Peach et al., 1990, 1994; Stone et al., 1990), early experimental attempts to measure $D_{\mathrm{Pt}}^{\text {matte-sil }}$ directly are now thought to have been compromised by the presence of "nanonuggets" in run products. Nanonuggets consist of sub-micron particles of Pt metal and/or Pt-rich sulphides globules that remain suspended in the silicate melt, resulting in an overestimate of the $\mathrm{Pt}$ content in the quenched glass, which lead to $D_{\mathrm{Pt}}^{\text {matte-sil }}$ that may be orders of magnitude too low (e.g., O’Neill et al., 1995; Ertel et al., 1999, 2008). The advent of laser-ablation ICP-MS as a microanalytical method suitable for determining PGEs in experimental run products has confirmed the ubiquity of the nanonugget problem.

As pointed out by O'Neill et al. (1995), the customary experimental tactic of performing "reversal" experiments to test for equilibrium does not address the nanonugget problem. The "reversal" tactic was introduced into experimental petrology specifically to guard against erroneous results that often arise in silicate systems due to sluggish nucleation and growth, and is irrelevant to sulphide/silicate melt partitioning experiments where nucleation is not an issue and diffusion kinetics are rapid. Instead, the different problems of PGE partitioning experiments demand that other criteria be used to assess equilibrium, such as demonstration of a smooth response to variations in the physical variables to which partitioning is expected to be sensitive, particularly oxygen fugacity $\left(f \mathrm{O}_{2}\right)$ and sulphur fugacity $\left(f \mathrm{~S}_{2}\right)$. At present, no studies that have tried to measure PGE matte/silicate partitioning directly have attempted the appropriate tests for equilibrium.

Unless special experimental techniques can be found to eliminate the nanonugget problem (e.g., Brenan, 2008), the PGE partitioning needed to discriminate between models must be obtained indirectly, by performing experiments under conditions where nanonuggets do not pose an over- 
whelming obstacle to measuring equilibrium relations, and then combining the results in a thermodynamic model to calculate the desired quantities, such as $D_{\mathrm{PGE}}^{\text {matte-sil }}$. This approach also has the advantage that the sensitivity of $D_{\mathrm{Pt}}^{\text {matte-sil }}$ to petrologically important variables is also obtained.

Here we report experiments in which the solubility of $\mathrm{Pt}$ in mattes was investigated as a function of $f \mathrm{O}_{2}, f \mathrm{~S}_{2}$ and temperature. The results may be combined with solubility data for Pt in silicate melts at 1 bar of Ertel et al. (1999), Borisov and Palme (1997, 2000), and Fortenfant et al. (2003), and the activity-composition relationships of $\mathrm{Pt}-\mathrm{Fe}$ alloys (Gudmundsson and Holloway, 1993), to calculate $D_{\mathrm{Pt}}^{\text {matte-sil }}$ over a range of conditions that are pertinent to the upper mantle and crust. We shall show that the very high values of $D_{\mathrm{PGE}}^{\text {matte-sil }}$ calculated by this method require that the high-temperature equilibrium between a matte and a silicate melt will lead to the matte being greatly enriched in Pt.

\section{EXPERIMENTAL METHODS}

Three sets of experiments were carried out to evaluate the effects of $T, f \mathrm{O}_{2}$ and $f \mathrm{~S}_{2}$ separately on the solubility of $\mathrm{Pt}$ in mattes. For each set of experiments two thermodynamic variables were kept constant while the third was varied. The experimental set-up was the same for all experiments. Each experimental charge consisted of troilite $(\mathrm{Fe} / \mathrm{S}$ atomic $=1)$ powder of $99.99 \%$ purity placed inside an open capsule made from pure $\mathrm{SiO}_{2}$ glass, and contained a loop of $\mathrm{Pt}$ wire. The crucibles were suspended in a vertical muffle tube furnace equipped for gas mixing, in which both $f \mathrm{O}_{2}$ and $f \mathrm{~S}_{2}$ were controlled independently using $\mathrm{CO}_{2}-\mathrm{CO}-\mathrm{SO}_{2}$ gas mixtures. The gas flows were measured using Tylan F2800 mass flow controllers. Two controllers were available for each gas: for $\mathrm{CO}$ and $\mathrm{CO}_{2}$ the controller had ranges between 0-10 and 0-200 SCCM (standard cubic centimeters per minute) and $0-10$ and 0 $100 \mathrm{SCCM}$ for $\mathrm{SO}_{2}$. The $f \mathrm{O}_{2}$ and $f \mathrm{~S}_{2}$ for each run were calculated using the thermodynamic data for gas species in the NIST-JANAF tables (Chase, 1998) according to O'Neill and Mavrogenes (2002). Temperature was held constant to $\pm 5^{\circ}$ for the duration of each run using a central Pt-Rh thermocouple external to the muffle tube. Run times of 96,72 and $24 \mathrm{~h}$ were used to ensure equilibrium between the $\mathrm{Pt}$ metal and the mattes in the runs performed at 1200,1300 and $1400{ }^{\circ} \mathrm{C}$, respectively. Equilibrium was subsequently tested by analysing $\mathrm{Fe}$ and $\mathrm{Pt}$ in line profiles through sections of the $\mathrm{Pt}$ wire and the $\mathrm{Pt}$ content of the matte at different run times (between 1 and $96 \mathrm{~h}$ ) and constant $f \mathrm{~S}_{2}(0.001$ bars $), f \mathrm{O}_{2}\left(10^{-11}\right.$ bars $)$ and temperature $\left(1200{ }^{\circ} \mathrm{C}\right)$. Profiles of the metal wire at the end of each run (Fig. 1A), showed that the wire is strongly zoned at run times of less than $4 \mathrm{~h}$, and homogeneous after $24 \mathrm{~h}$ run time. The activity of $\mathrm{Pt}$ is higher in the beginning of a run because $\mathrm{Fe}$ has not diffused completely into the metal wire. This led to the zonation of the metal wire with respect to $\mathrm{Pt}$ (Fig. 1A), and higher concentrations of $\mathrm{Pt}$ in the matte (Fig. 1B) at 1 and $4 \mathrm{~h}$ of run time. However, after $24 \mathrm{~h}$ of run time, the metal wire reaches its equilibrium $\mathrm{Fe}$ and $\mathrm{Pt}$ contents, (Fig. 1A), and displays a con-
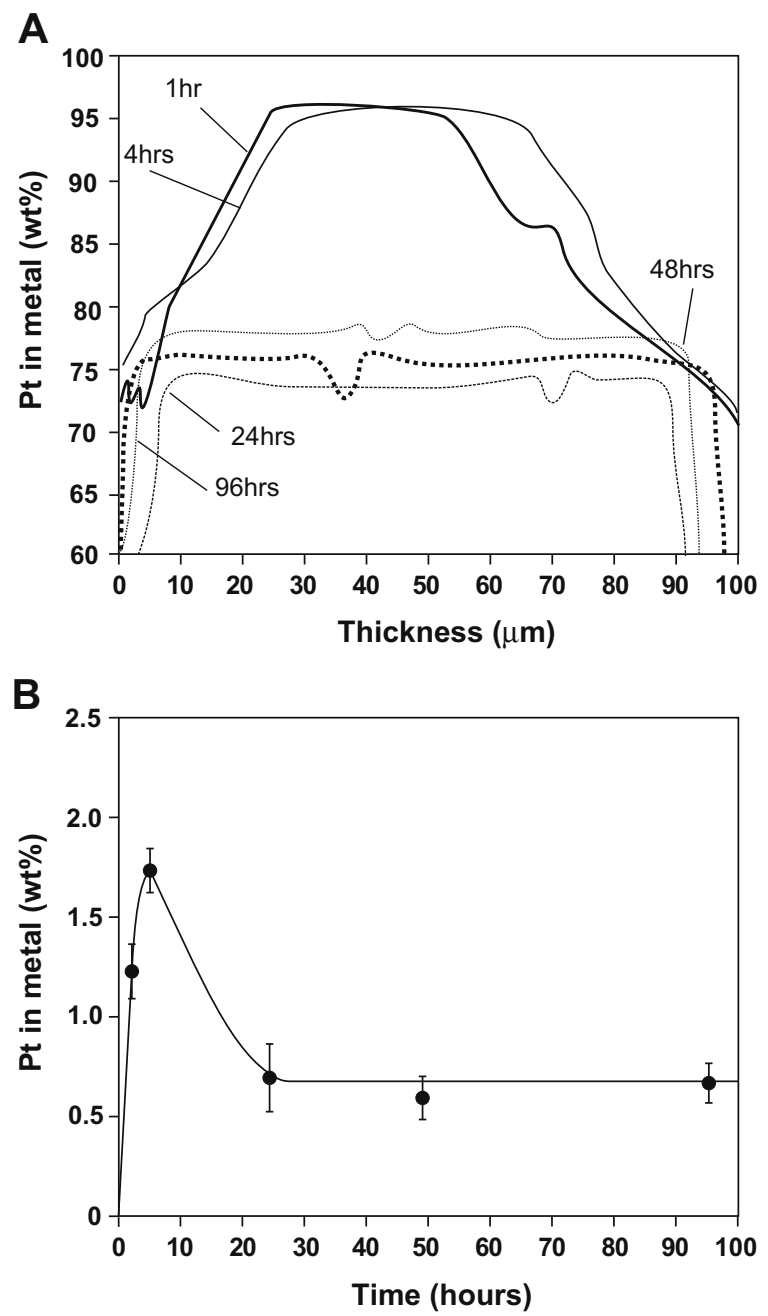

Fig. 1. (A) Profile of the Pt content of the metal phase for different run times. Curves represent five point moving averages derived from 30 to 50 EMP point analyses for each profile. (B) Pt content in matte at different run times. Time series carried out at constant $f \mathrm{~S}_{2}(0.001$ bars $), f \mathrm{O}_{2}\left(10^{-11}\right.$ bars $)$ and temperature $\left(1200^{\circ} \mathrm{C}\right)$.

stant Pt solubility in the matte over time (Fig. 1B). At the end of each run the charges were quenched by dropping them into a beaker of water at room temperature. The experimental products were then recovered, mounted in epoxy resin and polished for analysis.

\section{ANALYTICAL METHODS}

\subsection{Petrographical description}

Unlike many silicate liquids, mattes do not quench to a glass but to a texturally complex mass of crystalline sulphide, metals and oxides, depending on the composition, requiring special care in determining the composition of the original matte.

Fig. 2B is a $\mathrm{Pt} \mathrm{X}$-ray map of a typical quenched experimental run, which shows that a Pt metal phase exsolves from the matte during quenching. In addition, a depletion halo, $\sim 40 \mu \mathrm{m}$ wide, formed around the original Pt-rich 


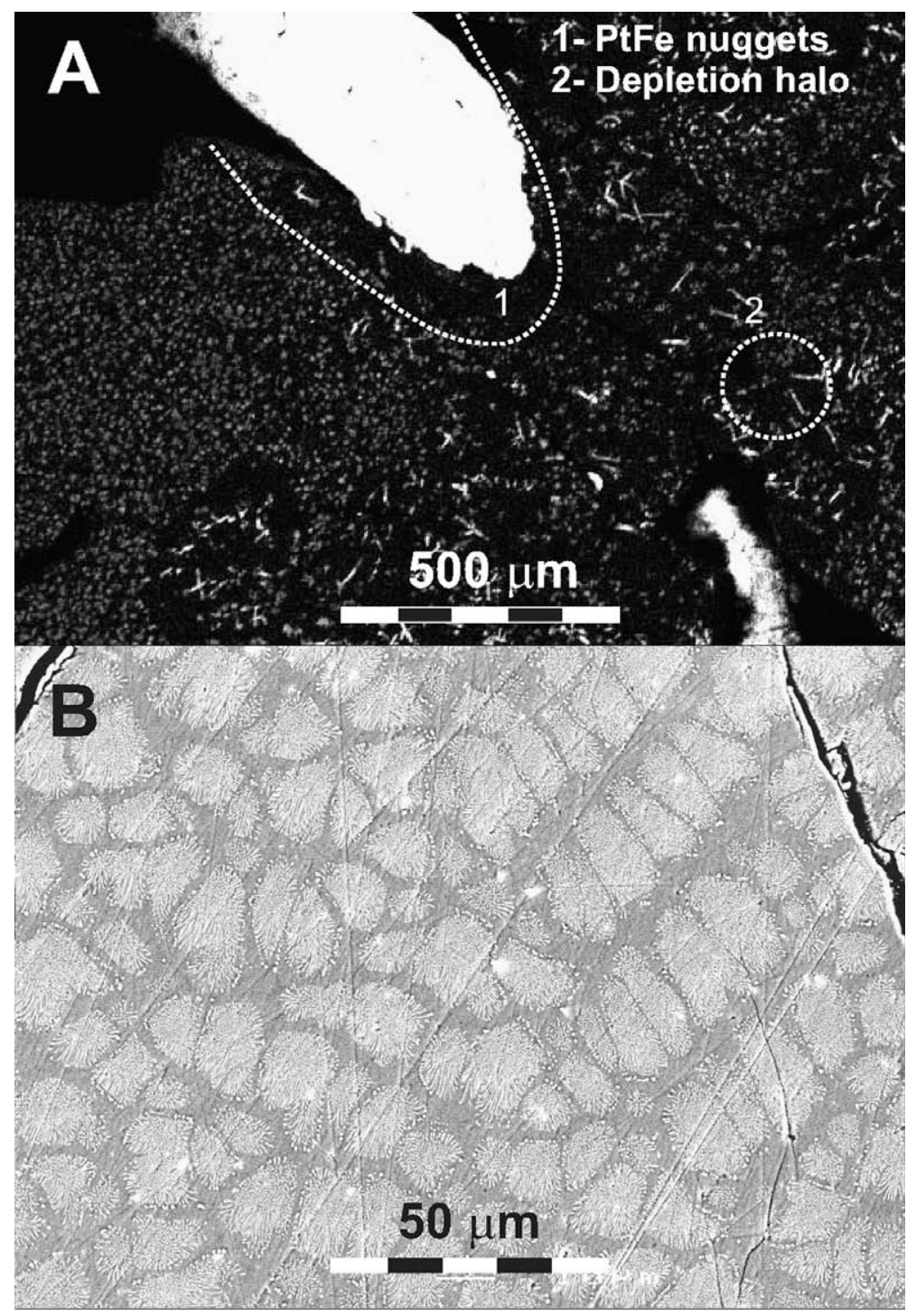

Fig. 2. (A) Pt X-ray map of run PtO11 for Pt. The original Pt metal (in the top center) is surrounded by a depletion halo (1) where no Pt is observed due to Pt diffusion into the Pt wire during quenching. The sulphide phase includes quench nuggets of PtFe metal (2) which exsolved from the matte during quenching. (B) Backscatter electron image of run PtS1. This is a typical run product where nuggets of PtFe are rosette shaped indicating they are a product of quenching.

metal upon quenching. A closer look at the PtFe quench nuggets shows typical quench textures (Fig. 2B), which indicates that these nuggets are the result of exsolution of dissolved Pt in the matte. The scale of the quench textures also varies depending on which part of the charge is considered. The quench nuggets tend to be larger near the center of the crucible because quenching is slower. Moreover, the shape of the quench nuggets is dependent on the $f \mathrm{~S}_{2}$ of the run, which controls the speciation of $\mathrm{Pt}$ in the matte. Any measurement of the Pt content of the matte has to include these Pt-rich quench nuggets, as they represent $\mathrm{Pt}$ that was dissolved in the matte prior to quenching. This requires the experiments to be performed at a scale sufficiently large to produce areas of quenched sulphide suitable for representative analyses.

\subsection{Electron microprobe analysis - major elements}

Both sulphide and metal phases were analysed using the CAMECA-SX100 Electron Microprobe, in wavelength dispersive mode (WDS), with $15 \mathrm{kV}$ acceleration voltage and $20 \mathrm{nA}$ beam current. The alloys were analysed using line profiles across the wire, and the sulphides as area scans in $300 \mu \mathrm{m} \times 300 \mu \mathrm{m}$ grids. Standard calibrations were carried out using $\mathrm{Pt}_{0.7} \mathrm{Rh}_{0.3}$ metal for $\mathrm{Pt}$ and pure troilite for $\mathrm{Fe}$ and $\mathrm{S}$. Oxygen was analysed using the CAMECA-SX100 EMPA, in WDS mode. Calibrations for $\mathrm{O}$ were conducted on rutile $\left(\mathrm{TiO}_{2}\right)$, chromite and quartz using the PC0 monolayer pseudocrystal, following the methodology described in detail in Fonseca et al. (2008). 


\subsection{Laser ablation mass spectrometry (LA-ICP-MS) - trace elements}

LA-ICP-MS was used for trace element analysis in the sulphide phase, following the procedure described by Fonseca et al. (2007) with ${ }^{57} \mathrm{Fe}$ as the internal standard. The standard used was the CANMET727T2 synthetic PGE and $\mathrm{Au}$ bearing FeS from the Memorial University of Newfoundland. The spot size for all analyses was $112 \mu \mathrm{m}$, the laser repetition rate was $5 \mathrm{~Hz}$, and the laser pulse energy was $120 \mathrm{~mJ}$ with $\sim 75 \%$ energy loss, resulting in a fluence of $\sim 265 \mathrm{~J} \mathrm{~cm}^{-2}$. The Pt isotopes ${ }^{194} \mathrm{Pt},{ }^{195} \mathrm{Pt}$ and ${ }^{196} \mathrm{Pt}$ were analysed, which produced results in good agreement with each other, showing that there were no significant interferences from other isotopes or molecular compounds. Platinum metal has a very low vapor pressure when compared to mattes. It is therefore possible that, during ablation of the sample, Pt alloys may not ablate at the same rate as the matte matrix, resulting in lower measured Pt concentrations. This possibility was tested by measuring Pt contents in matte over a range of laser pulse energies, between $\sim 25 \mathrm{~mJ}$ (100 mJ laser output, filtered by $25 \%$ optical mirror), and $160 \mathrm{~mJ}$ (no transmission loss). The measured $\mathrm{Pt}$ concentrations in mattes were constant over the range of laser pulse energies used, indicating that Pt alloys are not fractionated relative to $\mathrm{Fe}$ and $\mathrm{S}$ in the matte during ablation.

\section{THEORETICAL BACKGROUND}

The solubility of $\mathrm{Pt}$ in mattes requires an understanding of the effects of several competing variables, the most important of which are likely to be temperature, $f S_{2}$ and $f \mathrm{O}_{2}$. Platinum could dissolve in a matte as oxide, sulphide and metal species, with solution reactions taking the following form:

$$
\begin{aligned}
& \mathrm{Pt}_{\text {solid }}+\frac{x}{4} \mathrm{~S}_{2}=\mathrm{Pt}^{(+x)} \mathrm{S}_{\frac{x}{2} \text { matte }} \\
& \mathrm{Pt}_{\text {solid }}+\frac{x}{4} \mathrm{O}_{2}=\mathrm{Pt}^{(+x)} \mathrm{O}_{\frac{2}{2} \text { matte }} \\
& \mathrm{Pt}_{\text {solid }}=\mathrm{Pt}_{\text {matte }}
\end{aligned}
$$

where $x$ is the effective valence state of $\mathrm{Pt}$ in the matte. The common valence state of $\mathrm{Pt}$ in silicate melts in the oxygen fugacity regime of the terrestrial upper mantle appears to be $\mathrm{Pt}^{2+}$, but $\mathrm{Pt}^{4+}$ occurs at higher $\mathrm{fO}_{2}$ (O'Neill et al., 1995; Ertel et al., 1999), and is the common higher oxidation state of $\mathrm{Pt}$ in many chemical compounds. Any change in valence must profoundly affect the solubility of $\mathrm{Pt}$ in mattes, and experiments that do not address his most important aspect of PGE chemistry cannot be extrapolated to natural systems reliably.

\section{RESULTS}

\subsection{Activities of $\mathrm{Fe}$ and $\mathrm{Pt}$ in the metal phase}

The major element composition of mattes and alloys, as well as the experimental run conditions, are presented in Table 2. The results show that the Pt-rich metal phase in equilibrium with the sulphide-rich matte in the experimental runs display varying concentrations of $\mathrm{Fe}$, which changes the activity of $\mathrm{Pt}\left(a_{\mathrm{Pt}}^{\text {metal }}\right)$ in the system $\mathrm{Fe}-\mathrm{Pt}-\mathrm{S}$ $\mathrm{O}$. The Pt-Fe binary shows a very strong negative deviation from Henry's law (Gudmundsson and Holloway, 1993; Okamoto, 2002). Since the majority of the (Pt,Fe) alloys obtained in the experimental runs in this study fell within the face-centered cubic continuous solid solution ( $\gamma$-phase) field in the FePt phase diagram, the activities of $\mathrm{Pt}$ and $\mathrm{Fe}$ in the metal were calculated from the equations of Gudmundsson and Holloway (1993):

$$
\begin{aligned}
& \log \gamma_{\mathrm{Fe}}=\left(1-X_{\mathrm{Fe}}\right)^{2}\left[B+C\left(4 X_{\mathrm{Fe}}-1\right)\right] \\
& \log \gamma_{\mathrm{Pt}}=X_{\mathrm{Fe}}^{2}\left[B+C\left(4 X_{\mathrm{Fe}}-3\right)\right]
\end{aligned}
$$

where $\gamma_{\mathrm{Pt}}$ and $\gamma_{\mathrm{Fe}}$ are the activity coefficients of $\mathrm{Pt}$ and $\mathrm{Fe}$, respectively, $X_{\mathrm{Fe}}$ is the mole fraction of $\mathrm{Fe}$ in the metal, and $B$ and $C$ are temperature-dependent constants. Gudmundsson and Holloway (1993) only determined $B$ and $C$ for the temperatures of 1300 and $1400^{\circ} \mathrm{C}$. Since our experimental runs were also conducted at $1200{ }^{\circ} \mathrm{C}$, the values for these constants were linearly extrapolated to lower temperatures following Pruseth and Palme (2004), yielding:

$B=0.0062 T-12.302$

$C=0.0017 T-2.565$

A listing of all activity coefficients and activities of $\mathrm{Pt}$ and $\mathrm{Fe}$ is provided in Table 3. Measured concentrations of $\mathrm{Pt}$ in the matte may be normalised to unit activity of $\mathrm{Pt}$ in the alloy (i.e., $a_{\mathrm{Pt}}^{\text {metal }}=1$ ) using $[\mathrm{Pt}]_{\text {matte }}^{a_{\text {norm }}}=$ $[\mathrm{Pt}]_{\text {matte }} / a_{\mathrm{Pt}}^{\text {metal }}[\mathrm{Pt}]$ (Table 3).

\subsection{The effect of $f S_{2}$}

The effect of $f \mathrm{~S}_{2}$ on the solubility of $\mathrm{Pt}$ in mattes was investigated through experiments that were carried out at a constant $f \mathrm{O}_{2}$ of $10^{-13.0}$ bar ( QFM-5) at $1200{ }^{\circ} \mathrm{C}$, and $10^{-11.3}$ bar ( $\sim$ QFM-4) at $1300{ }^{\circ} \mathrm{C}$, and over a range of $f \mathrm{~S}_{2}$ between $10^{-4.9}$ and $10^{-1.3}$ bar. The Pt concentrations in matte increase with increasing $f \mathrm{~S}_{2}$ (Fig. 3A). The normalised solubility of $\mathrm{Pt}$ in the matte $\left([\mathrm{Pt}]_{\text {matte }}^{a-\text { norm }}\right)$ shows the same behaviour as the raw solubility data, in that $\mathrm{Pt}$ concentrations increase with increasing $f \mathrm{~S}_{2}$ except at $f \mathrm{~S}_{2}>10^{4}$. The slope of 0.47 given by an empirical fit to the activity normalised data in Fig. 3A suggests a valency of $\mathrm{Pt}^{2+}$. At these $f \mathrm{~S}_{2},[\mathrm{Pt}]_{\text {matte }}^{a-n o r m}$ increases whereas the raw solubility decreases. Matte composition also changed with $f \mathrm{~S}_{2}$, from $\mathrm{Fe} / \mathrm{S}$ (atomic fraction) $\sim 0.9$ at high $f \mathrm{~S}_{2}$, to $\sim 1.2$ at low $f \mathrm{~S}_{2}$ (Fig. 3B).

\subsection{The effect of $f \mathrm{O}_{2}$}

Kress (1997, 2007), Larocque et al. (2000), Fonseca et al. (2008), and Moretti and Baker (2008) investigated the effects of $f \mathrm{O}_{2}$ and $f \mathrm{~S}_{2}$ in the system $\mathrm{Fe}-\mathrm{S}-\mathrm{O}$ and observed that a considerable amount of oxygen $(\sim 7 \mathrm{wt} \% \mathrm{O})$ was dissolved in the matte at the $f \mathrm{O}_{2}$ defined by the quartz-fayalite-magnetite buffer (QFM). If $\mathrm{O}$ dissolves in the matte, the possible effect of $f \mathrm{O}_{2}$ needs to be investigated in view of reaction 2. Andrews and Brenan (2002) studied the effect of $f \mathrm{O}_{2}$ (as 
Table 2

Experimental conditions and major and trace element concentrations.

\begin{tabular}{|c|c|c|c|c|c|c|c|c|c|c|c|}
\hline \multirow[t]{2}{*}{ Run } & \multicolumn{5}{|c|}{ Run conditions } & \multicolumn{5}{|c|}{ Composition of the sulphide matte } & \multirow[t]{2}{*}{$X_{\mathrm{Pt}}^{\text {metal }}$} \\
\hline & $-\log f \mathrm{~S}_{2}$ & $-\log f \mathrm{O}_{2}$ & $\mathrm{Pt} / \mathrm{FeS}^{\mathrm{a}}$ & $T\left({ }^{\circ} \mathrm{C}\right)$ & Run time (h) & $\mathrm{Fe}\left(w \mathrm{t}^{\%} \%\right)$ & $\mathrm{S}(\mathrm{wt} \%)$ & $\mathrm{O}(\mathrm{wt} \%)$ & $\mathrm{Pt}(\mathrm{ppm})$ & Total $(w t \%)$ & \\
\hline Pt1h & 2.94 & 10.9 & 0.2 & 1200 & 1 & $63.9 \pm 0.3$ & $33.2 \pm 0.1$ & $0.8 \pm 0.2$ & $11204 \pm 1512$ & 99.0 & 0.65 \\
\hline Pt4h & 2.94 & 10.9 & 0.2 & 1200 & 4 & $62.3 \pm 0.2$ & $36.4 \pm 0.3$ & $1.5 \pm 0.3$ & $17103 \pm 3210$ & 101.9 & 0.83 \\
\hline Pt24h & 2.94 & 10.9 & 0.2 & 1200 & 24 & $59.1 \pm 0.4$ & $36.7 \pm 0.8$ & $1.6 \pm 0.1$ & $11488 \pm 948$ & 98.6 & 0.53 \\
\hline Pt48h & 2.94 & 10.9 & 0.2 & 1200 & 48 & $58.2 \pm 0.4$ & $39.8 \pm 0.1$ & $2.4 \pm 0.4$ & $6146 \pm 675$ & 101.0 & 0.52 \\
\hline Pt96h/PtO11 & 2.94 & 10.9 & 0.2 & 1200 & 96 & $64.1 \pm 0.1$ & $33 \pm 0.4$ & $3.5 \pm 0.2$ & $6234 \pm 1567$ & 101.2 & 0.54 \\
\hline $\mathrm{PtO} 9^{\mathrm{b}}$ & 3.05 & 9.0 & 0.2 & 1200 & 96 & $52.8 \pm 0.5$ & $6.1 \pm 1.1$ & $29.8 \pm 0.8$ & $3 \pm 2$ & 88.7 & 0.88 \\
\hline PtO10 & 2.94 & 10.3 & 0.2 & 1200 & 96 & $64.8 \pm 0.1$ & $27.4 \pm 0.2$ & $6.91 \pm 0.5$ & $3189 \pm 122$ & 99.4 & 0.52 \\
\hline PtO11/Pt96h & 2.94 & 10.9 & 0.2 & 1200 & 96 & $64.1 \pm 0.2$ & $33.0 \pm 0.3$ & $3.46 \pm 0.4$ & $3785 \pm 39$ & 100.9 & 0.51 \\
\hline PtO12 & 2.24 & 11.8 & 0.2 & 1200 & 96 & $64 \pm 0.1$ & $32.6 \pm 0.4$ & $2.1 \pm 0.1$ & $6898 \pm 916$ & 99.4 & 0.52 \\
\hline PtO13/PtS3 & 2.94 & 12.9 & 0.2 & 1200 & 96 & $64.6 \pm 0.5$ & $34.2 \pm 0.2$ & $0.5 \pm 0.1$ & $6112 \pm 1121$ & 99.9 & 0.49 \\
\hline PtO15 & 3.05 & 14.9 & 0.2 & 1200 & 96 & $60.9 \pm 0.6$ & $35.2 \pm 0.2$ & bdlc & $25354 \pm 375$ & 98.6 & 0.5 \\
\hline $\mathrm{PtS1} / \mathrm{PtH} 2$ & 1.31 & 11.8 & 0.2 & 1200 & 96 & $58.5 \pm 0.4$ & $35.1 \pm 0.6$ & $0.2 \pm 0.1$ & $62927 \pm 1939$ & 100.1 & 0.63 \\
\hline PtS2 & 2.21 & 12.9 & 0.2 & 1200 & 96 & $62.9 \pm 0.1$ & $34.9 \pm 0.5$ & $0.2 \pm 0.1$ & $26525 \pm 715$ & 100.7 & 0.6 \\
\hline PtS3/PtO13 & 2.94 & 12.9 & 0.2 & 1200 & 96 & $64.6 \pm 0.2$ & $34.2 \pm 0.4$ & $0.3 \pm 0.1$ & $6112 \pm 1121$ & 99.7 & 0.49 \\
\hline PtS4 & 3.96 & 12.8 & 0.2 & 1200 & 96 & $66.1 \pm 0.4$ & $33.6 \pm 0.1$ & $0.4 \pm 0.1$ & $1665 \pm 273$ & 100.3 & 0.42 \\
\hline PtS5 & 4.96 & 13.1 & 0.2 & 1200 & 96 & $66.0 \pm 0.9$ & $32.5 \pm 0.1$ & $1.5 \pm 0.3$ & $816 \pm 259$ & 100.0 & 0.33 \\
\hline PtH1 & 2.21 & 13.1 & 0.1 & 1200 & 96 & $64.1 \pm 1.1$ & $35.2 \pm 0.4$ & bdl & $7700 \pm 529$ & 100.1 & 0.51 \\
\hline PtH2 & 1.31 & 11.8 & 0.2 & 1200 & 96 & $58.5 \pm 0.5$ & $35.1 \pm 0.3$ & bdl & $62967 \pm 1263$ & 99.9 & 0.7 \\
\hline PtH3 & 2.21 & 12.9 & 1.0 & 1200 & 96 & $57.9 \pm 0.1$ & $34.6 \pm 0.5$ & bdl & $62927 \pm 1939$ & 98.8 & 0.8 \\
\hline $\mathrm{Pt} \# 1$ & 1.61 & 11.3 & 0.2 & 1300 & 72 & $58.4 \pm 0.1$ & $34.8 \pm 0.1$ & $0.2 \pm 0.1$ & $55622 \pm 2491$ & 99.0 & 0.62 \\
\hline $\mathrm{Pt} \# 2$ & 1.81 & 11.3 & 0.2 & 1300 & 72 & $60.2 \pm 0.2$ & $33.9 \pm 0.1$ & $0.3 \pm 0.2$ & $45000 \pm 3741$ & 98.9 & 0.6 \\
\hline $\mathrm{Pt} \# 3$ & 2.10 & 11.3 & 0.2 & 1300 & 72 & $61.4 \pm 0.5$ & $34.1 \pm 0.3$ & $0.9 \pm 0.3$ & $30650 \pm 4030$ & 99.5 & 0.57 \\
\hline $\mathrm{Pt} \# 4$ & 2.48 & 11.4 & 0.2 & 1300 & 72 & $63.5 \pm 0.1$ & $33.6 \pm 0.1$ & $0.6 \pm 0.1$ & $17807 \pm 2167$ & 99.5 & 0.54 \\
\hline $\mathrm{Pt} \# 5$ & 2.84 & 11.4 & 0.2 & 1300 & 72 & $64.4 \pm 0.1$ & $33.1 \pm 0.2$ & $1.5 \pm 0.2$ & $8500 \pm 674$ & 99.9 & 0.5 \\
\hline $\mathrm{Pt} \# 6$ & 3.15 & 11.2 & 0.2 & 1300 & 72 & $64.5 \pm 0.3$ & $31.7 \pm 0.6$ & $2.0 \pm 0.2$ & $6573 \pm 386$ & 98.9 & 0.48 \\
\hline Pt\#7 & 3.64 & 11.4 & 0.2 & 1300 & 72 & $63.5 \pm 0.8$ & $33.8 \pm 0.2$ & $2.1 \pm 0.5$ & $6027 \pm 661$ & 100.0 & 0.5 \\
\hline Pt\#8 & 3.05 & 13.7 & 0.2 & 1300 & 72 & $63.7 \pm 0.1$ & $34.4 \pm 0.8$ & $0.5 \pm 0.3$ & $12210 \pm 679$ & 99.8 & 0.5 \\
\hline Pt\#9 & 2.88 & 12.7 & 0.2 & 1300 & 72 & $63.3 \pm 0.4$ & $34.2 \pm 0.3$ & $1.1 \pm 0.2$ & $13408 \pm 2250$ & 99.9 & 0.49 \\
\hline $\mathrm{Pt} \# 10$ & 2.83 & 10.3 & 0.2 & 1300 & 72 & $64.5 \pm 0.5$ & $30.5 \pm 0.1$ & $4.0 \pm 0.7$ & $7474 \pm 485$ & 99.7 & 0.52 \\
\hline $\mathrm{Pt} \# 11^{\mathrm{c}}$ & 2.94 & 9.7 & 0.2 & 1300 & 72 & $52.9 \pm 1.1$ & $5.6 \pm 0.9$ & $28.6 \pm 0.5$ & $97 \pm 2$ & 87.1 & 0.54 \\
\hline $\mathrm{Pt} \# 12$ & 1.58 & 10.3 & 0.2 & 1400 & 24 & $59.4 \pm 0.7$ & $33.9 \pm 0.2$ & $1.1 \pm 0.3$ & $41524 \pm 6630$ & 98.6 & 0.59 \\
\hline $\mathrm{Pt} \# 13$ & 3.88 & 10.3 & 0.2 & 1400 & 24 & $61.7 \pm 0.2$ & $33.4 \pm 0.3$ & $2.8 \pm 0.6$ & $27437 \pm 3149$ & 100.6 & 0.57 \\
\hline $\mathrm{Pt \# 14}$ & 1.61 & 11.3 & 0.8 & 1300 & 72 & $59.2 \pm 0.1$ & $34.5 \pm 0.1$ & bdl & $61227 \pm 1564$ & 99.8 & 0.62 \\
\hline $\mathrm{Pt} \# 15$ & 1.61 & 11.3 & 1.0 & 1300 & 72 & $58.8 \pm 0.0$ & $34.0 \pm 0.5$ & bdl & $70950 \pm 1294$ & 99.9 & 0.62 \\
\hline
\end{tabular}

Initial $\mathrm{Pt} / \mathrm{FeS} \mathrm{wt} \%$ of the experimental charge.

${ }^{b}$ Reacted extensively with the $\mathrm{SiO}_{2}$ capsule with $11.1 \mathrm{wt} \% \mathrm{Si}$ dissolved in the matte.

${ }^{\mathrm{c}}$ Reacted extensively with the $\mathrm{SiO}_{2}$ capsule with $10.9 \mathrm{wt} \% \mathrm{Si}$ dissolved in the matte. 
Table 3

Calculate activity coefficients for Pt in the metal phase and correspondent paritition coefficients.

\begin{tabular}{|c|c|c|c|c|c|c|c|}
\hline Run & $\gamma_{\mathrm{Pt}}^{\text {metala }}$ & $a_{\mathrm{Pt}}^{\text {metal }}$ & {$[\mathrm{Pt}]_{\text {matte }}^{a \text { norm }}(\mathrm{wt} \%)^{\mathrm{b}}$} & {$[\mathrm{Pt}]_{\text {sil-melt }}(\mathrm{ppb})^{\mathrm{c}}$} & $D_{\mathrm{Pt}}^{\text {metal/matte }}$ & $D_{\mathrm{Pt}}^{\text {metal/sil }}$ & $D_{\mathrm{Pt}}^{\text {matte/sil }}$ \\
\hline Ptlh & 0.327 & 0.214 & 5.2 & 0.0274 & 77 & $3.65 \times 1010$ & $4.75 \times 10^{8}$ \\
\hline $\mathrm{Pt} 4 \mathrm{~h}$ & 0.79 & 0.658 & 2.6 & 0.0274 & 55 & $3.65 \times 10^{10}$ & $6.63 \times 10^{8}$ \\
\hline Pt24h & 0.111 & 0.058 & 19.7 & 0.0274 & 69 & $3.65 \times 10^{10}$ & $5.28 \times 10^{8}$ \\
\hline $\mathrm{Pt} 48 \mathrm{~h}$ & 0.1 & 0.052 & 11.9 & 0.0274 & 127 & $3.65 \times 10^{10}$ & $2.87 \times 10^{8}$ \\
\hline Pt96h/PtO11 & 0.12 & 0.064 & 9.7 & 0.0274 & 130 & $3.65 \times 10^{10}$ & $2.80 \times 10^{8}$ \\
\hline PtO10 & 0.102 & 0.053 & 6 & 0.07901 & 251 & $1.27 \times 10^{10}$ & $5.05 \times 10^{8}$ \\
\hline PtO11/Pt96h & 0.094 & 0.048 & 7.9 & 0.0274 & 206 & $3.65 \times 10^{10}$ & $1.77 \times 10^{8}$ \\
\hline PtO12 & 0.104 & 0.054 & 12.8 & 0.00995 & 114 & $1.01 \times 10^{11}$ & $8.78 \times 10^{8}$ \\
\hline $\mathrm{PtO} 13 / \mathrm{PtS} 3$ & 0.077 & 0.038 & 16 & 0.00268 & 128 & $3.74 \times 10^{11}$ & $2.92 \times 10^{9}$ \\
\hline PtO15 & 0.086 & 0.043 & 58.8 & 0.00025 & 32 & $4.00 \times 10^{12}$ & $1.30 \times 10^{11}$ \\
\hline $\mathrm{PtS} 1 / \mathrm{PtH} 2$ & 0.283 & 0.179 & 35.2 & 0.00995 & 14 & $1.01 \times 10^{11}$ & $7.07 \times 10^{9}$ \\
\hline PtS2 & 0.216 & 0.13 & 20.5 & 0.0025 & 32 & $4.00 \times 10^{11}$ & $1.26 \times 10^{10}$ \\
\hline PtS3/PtO13 & 0.077 & 0.038 & 16 & 0.00268 & 128 & $3.74 \times 10^{11}$ & $2.92 \times 10^{9}$ \\
\hline PtS4 & 0.031 & 0.013 & 12.9 & 0.0025 & 437 & $4.00 \times 10^{11}$ & $9.17 \times 10^{8}$ \\
\hline PtS5 & 0.009 & 0.003 & 28.4 & 0.0025 & 792 & $4.00 \times 10^{11}$ & $5.05 \times 10^{8}$ \\
\hline PtH1 & 0.09 & 0.046 & 16.8 & 0.0025 & 104 & $4.00 \times 10^{11}$ & $3.87 \times 10^{9}$ \\
\hline PtH2 & 0.432 & 0.301 & 21 & 0.00995 & 14 & $1.01 \times 10^{11}$ & $7.07 \times 10^{9}$ \\
\hline PtH3 & 0.719 & 0.578 & 10.9 & 0.0025 & 15 & $4.00 \times 10^{11}$ & $2.71 \times 10^{10}$ \\
\hline Pt\#1 & 0.28 & 0.172 & 32.3 & 0.02458 & 15 & $4.07 \times 10^{10}$ & $2.68 \times 10^{9}$ \\
\hline $\mathrm{Pt} \# 2$ & 0.248 & 0.148 & 30.4 & 0.02458 & 18 & $4.07 \times 10^{10}$ & $2.20 \times 10^{9}$ \\
\hline $\mathrm{Pt} \# 3$ & 0.193 & 0.109 & 28.1 & 0.02458 & 26 & $4.07 \times 10^{10}$ & $1.54 \times 10^{9}$ \\
\hline $\mathrm{Pt} \# 4$ & 0.152 & 0.082 & 21.8 & 0.02458 & 45 & $4.07 \times 10^{10}$ & $9.01 \times 10^{8}$ \\
\hline $\mathrm{Pt} \# 5$ & 0.109 & 0.055 & 15.6 & 0.02458 & 93 & $4.07 \times 10^{10}$ & $4.37 \times 10^{8}$ \\
\hline Pt\#6 & 0.092 & 0.044 & 14.8 & 0.02458 & 118 & $4.07 \times 10^{10}$ & $3.44 \times 10^{8}$ \\
\hline $\mathrm{Pt} \# 7$ & 0.106 & 0.053 & 11.4 & 0.02458 & 130 & $4.07 \times 10^{10}$ & $3.12 \times 10^{8}$ \\
\hline $\mathrm{Pt} \# 8$ & 0.105 & 0.052 & 23.4 & 0.00157 & 64 & $6.37 \times 10^{11}$ & $9.99 \times 10^{9}$ \\
\hline $\mathrm{Pt} \# 9$ & 0.093 & 0.045 & 29.8 & 0.00514 & 58 & $1.95 \times 10^{11}$ & $3.39 \times 10^{9}$ \\
\hline $\mathrm{Pt} \# 10$ & 0.128 & 0.066 & 11.3 & 0.08234 & 107 & $1.21 \times 10^{10}$ & $1.14 \times 10^{8}$ \\
\hline $\mathrm{Pt} \# 12$ & 0.268 & 0.158 & 26.3 & 0.0814 & 20 & $1.23 \times 10^{10}$ & $6.12 \times 10^{8}$ \\
\hline $\mathrm{Pt} \# 13$ & 0.235 & 0.134 & 20.5 & 0.0814 & 30 & $1.23 \times 10^{10}$ & $4.08 \times 10^{8}$ \\
\hline $\mathrm{Pt} \# 14$ & 0.29 & 0.179 & 34.1 & 0.02458 & 14 & $4.07 \times 10^{10}$ & $2.90 \times 10^{9}$ \\
\hline Pt\#15 & 0.291 & 0.181 & 39.3 & 0.02458 & 12 & $4.07 \times 10^{10}$ & $3.34 \times 10^{9}$ \\
\hline
\end{tabular}

${ }^{a}$ Calculated from Eq. (5).

${ }^{\mathrm{b}} \mathrm{Pt}$ concentration in the matte normalised to unit activity $-[\mathrm{Pt}]_{\text {matte }} / a_{\mathrm{Pt}}^{\text {metal }}$.

${ }^{c}$ Calculated from Ertel et al. (1999) and corrected for temperature using Fortenfant et al. (2003).

well as $f \mathrm{~S}_{2}$ ) on the solubility of $\mathrm{Ru}$ in matte and found that increasing $f \mathrm{O}_{2}$ decreased the solubility of $\mathrm{Ru}$. They suggested that the observed negative correlation between $\mathrm{Ru}$ solubility and $f \mathrm{O}_{2}$ shows that $\mathrm{Ru}$ oxide is not a species in the matte and that the addition of oxygen raises $\gamma_{\mathrm{Ru}}^{\text {matte }}$. More recently, Fonseca et al. (2007) showed that Re solubility in sulphide-rich matte has no obvious dependence on $f \mathrm{O}_{2}$, except at $f \mathrm{O}_{2}$ larger than $\sim 10^{-10}$ bar where solubility decreases sharply due to the formation of an oxide-rich matte.

The influence of $f \mathrm{O}_{2}$ on the solubility of $\mathrm{Pt}$ in mattes was investigated through a series of experiments that were carried out at a nearly constant $f S_{2}$ of $\sim 10^{-3.0}$ bar and over a range of $f \mathrm{O}_{2}$, between $10^{-14.9}$ and $10^{-9.0}$ bar (QFM-6.6 and QFM-0.8) at $1200^{\circ} \mathrm{C}$ and between $10^{-13.7}$ and $10^{-9.6}$ bar (QFM-6.4 and QFM-2.3), at $1300^{\circ} \mathrm{C}$. The concentration of $\mathrm{Pt}$ in matte showing no clear dependence on $f \mathrm{O}_{2}$, except at $f \mathrm{O}_{2}>10^{-10}$ bar when solubility decreases sharply to less than $100 \mathrm{ppm}$ (Fig. 4A), indicating that $\mathrm{Pt}$ does not dissolve as an oxide component as in reaction 2 . The sharp decrease in $\mathrm{Pt}$ solubility in matte at $f \mathrm{O}_{2}>10^{-10}$ bar is probably due to the increasing amounts of oxygen dissolving into the matte at the expense of sul- phur, decreasing the amount of sulphur in the matte available to react with $\mathrm{Pt}$ (reaction 1). The matte also gets more metallic as $f \mathrm{O}_{2}$ decreases which is shown by the higher $\mathrm{Fe} /$ $(\mathrm{S}+\mathrm{O})$ of the matte a lower $f \mathrm{O}_{2}$ (Fig. 4B).

\subsection{The Pt-Fe-(S + O) pseudo-ternary}

The concentration of $\mathrm{Pt}$, in both metal and sulphide phases, can be plotted on the $\mathrm{Fe}-\mathrm{Pt}-(\mathrm{S}+\mathrm{O})$ pseudo-ternary diagram (Fig. 5). The results agree with the ternary plots of Pruseth and Palme (2004) at 1200 and $1300{ }^{\circ} \mathrm{C}$. Majzlan et al. (2002) and Pruseth and Palme (2004) observed that there is a direct correlation between high $\mathrm{Pt}$ concentrations in the matte and $\mathrm{Pt}$ contents of the alloys in equilibrium with the matte, for runs carried out at variable $f \mathrm{~S}_{2}$ (Fig. 5). The chemographic trend shown in the close ups in Fig. 5 suggests that Pt might dissolve into the melt as PtS, a well known Pt-bearing phase, with a valence of $\mathrm{Pt}^{2+}$, which is consistent with the good fit between the plotted data and the slope of the FeS-PtS binary seen in Fig. 3. The dissolution of $\mathrm{Pt}$ in the sulphide-rich matte as $\mathrm{PtS}$ is not surprising considering that the free energy of for- 


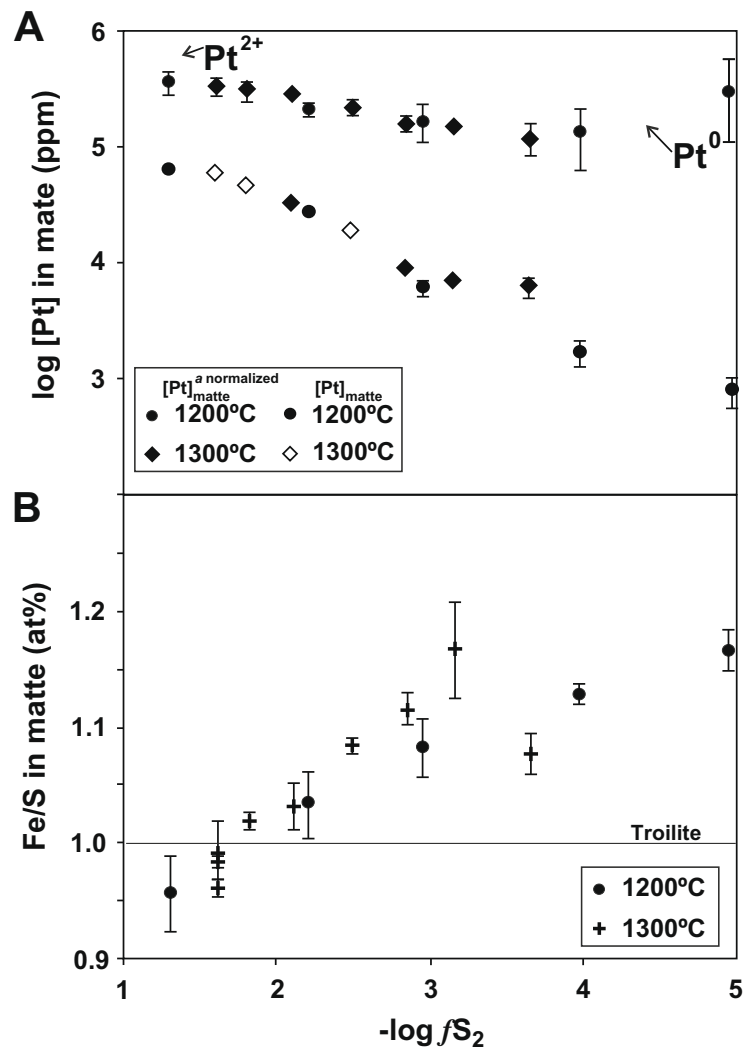

Fig. 3. Pt concentrations in matte in equilibrium with $\mathrm{Pt}$ metal at different $f \mathrm{~S}_{2}$ and constant $f \mathrm{O}_{2}$ at 1200 and $1300{ }^{\circ} \mathrm{C}$. Pt concentrations were normalised to unit activity of $\mathrm{Pt}$ because these experiments had significant amounts of $\mathrm{Fe}$ in the metal phase, therefore $[\mathrm{Pt}]_{\text {matte }}^{a-\text { norm }}=[\mathrm{Pt}]_{\text {matte }} / a_{\mathrm{Pt}}^{\text {metal }}$. Error bars $(2 \sigma$ standard error $)$ in log plot smaller than symbols. (B) $\mathrm{Fe} / \mathrm{S}$ (at \%) as a function of $f \mathrm{~S}_{2}$. Because the experimental system is an open one, matte composition changes over the range of $f \mathrm{~S}_{2}$ studied. Such a variation is demonstrated by the $\mathrm{Fe} / \mathrm{S}$ (at $\%$ ) of the matte, which approaches unity at high $f \mathrm{~S}_{2}$.

mation of $\mathrm{PtS}$, over the range of temperatures studied, is almost an order of magnitude lower than that of $\mathrm{PtS}_{2}$, which is not a known natural phase (Barin, 1989).

In runs where oxygen fugacity was varied, no such correlation is observed, because $\mathrm{Pt}$ does not dissolve as an oxide component as in reaction 4. According to Raghavan (1988), three distinct alloys are stable at the temperature of $1200{ }^{\circ} \mathrm{C}$, a $\gamma$ phase which represents a continuous solid solution between $\mathrm{Fe}$ and $\mathrm{Pt}$, and two ordered phases, FePt, and $\mathrm{FePt}_{3}$, representing miscibility gaps. At $1300{ }^{\circ} \mathrm{C}$, only $\gamma$ and $\mathrm{FePt}_{3}$ are present. All but one of the PtFe alloys analysed to date fall within or at the boundary of the $\gamma$ field. No significant difference was found in Pt solubility measurements in matte, between 1200 and $1300^{\circ} \mathrm{C}$, showing that temperature is not an important factor over the range studied, and therefore will not be considered further.

\subsection{Platinum solubility in mattes and $D_{\mathrm{Pt}}^{\text {mattesil }}$}

Previous experimental measurements of Pt solubility in silicate melts were obtained from Fe-free anorthite-diopside

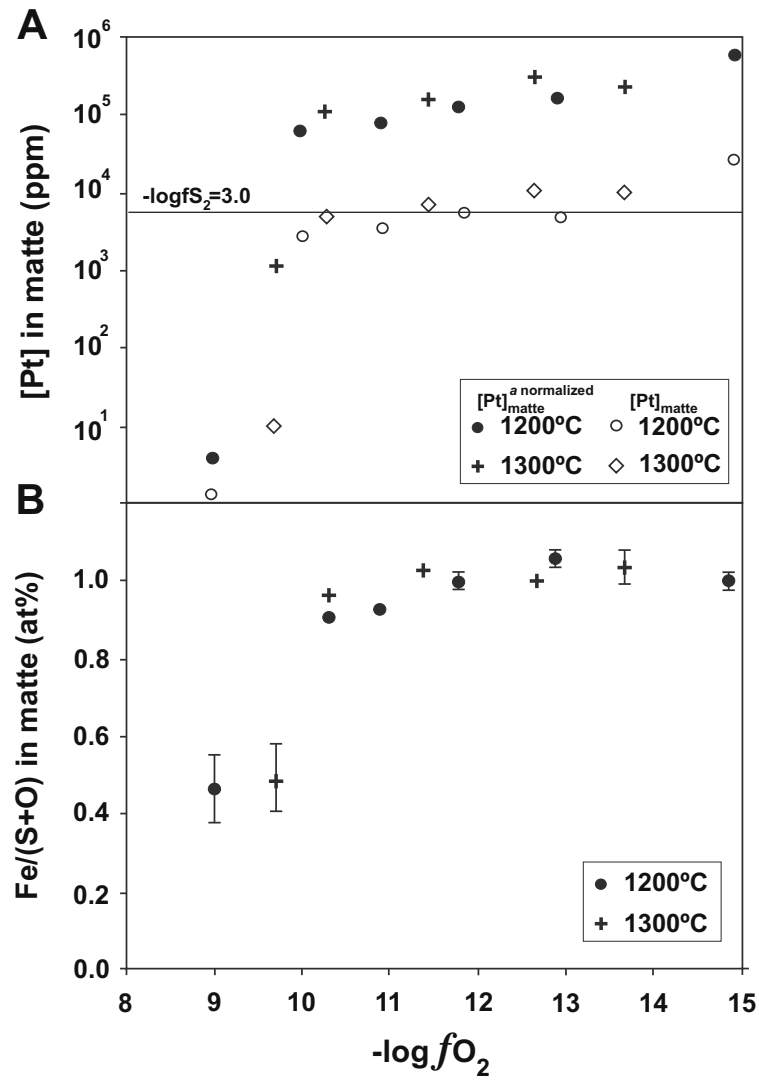

Fig. 4. (A) Pt concentrations in matte at different $f \mathrm{O}_{2}$, constant $f \mathrm{~S}_{2}$ and $1200-1300{ }^{\circ} \mathrm{C}$. Note that there is a small negative dependence of $\mathrm{Pt}$ contents on $f \mathrm{O}_{2}$ until at higher $f \mathrm{O}_{2}$ when Pt solubility suddenly drops. Error bars ( $2 \sigma$ standard error) smaller than symbols. (B) The metallic character of the matte $(\mathrm{FeS}+\mathrm{O})$ decreases with increasing $f \mathrm{O}_{2}$.

eutectic melts (Borisov and Palme, 1997; Ertel et al., 1999; Fortenfant et al., 2003). Moreover, as shown in Fig. 3B, matte composition, i.e., its molar $\mathrm{Fe} / \mathrm{S}$, changes as a function of $f \mathrm{~S}_{2}$ and $f \mathrm{O}_{2}$. It is therefore desirable to derive an expression that describes the partitioning of $\mathrm{Pt}$ between matte and silicate melt as a function of $f \mathrm{~S}_{2}$ and $f \mathrm{O}_{2}$, which is independent of the $\mathrm{Fe}$ content of the two phases. From the $\mathrm{Fe}-(\mathrm{S}+\mathrm{O})-\mathrm{Pt}$ ternary phase diagram (Fig. 5A and $\mathrm{B})$, it was established that $\mathrm{Pt}$ should dissolve into the sulphide-rich matte as $\mathrm{PtS}$ according to the reaction:

$\mathrm{Pt}^{\text {metal }}+\frac{1}{2} \mathrm{~S}_{2}(\mathrm{~g}) \rightarrow \mathrm{PtS}^{\text {matte }}$

for which the equilibrium is:

$\frac{-\Delta G(8)}{R T}=\ln a_{\mathrm{PtS}}^{\mathrm{matte}}-\frac{1}{2} \ln f \mathrm{~S}_{2}-\ln a_{\mathrm{Pt}}$

Because Pt dissolves in silicate melt at geologically relevant redox conditions as $\mathrm{Pt}^{2+}$ (Borisov and Palme, 1997; Ertel et al., 1999; Fortenfant et al., 2003):

$\mathrm{Pt}^{\text {metal }}+\frac{1}{2} \mathrm{O}_{2}(\mathrm{~g}) \rightarrow \mathrm{PtO}^{\text {sil }}$
$\frac{-\Delta G(10)}{R T}=\ln a_{\mathrm{PtO}}^{\text {sil }}-\frac{1}{2} \ln f \mathrm{O}_{2}-\ln a_{\mathrm{Pt}}$ 

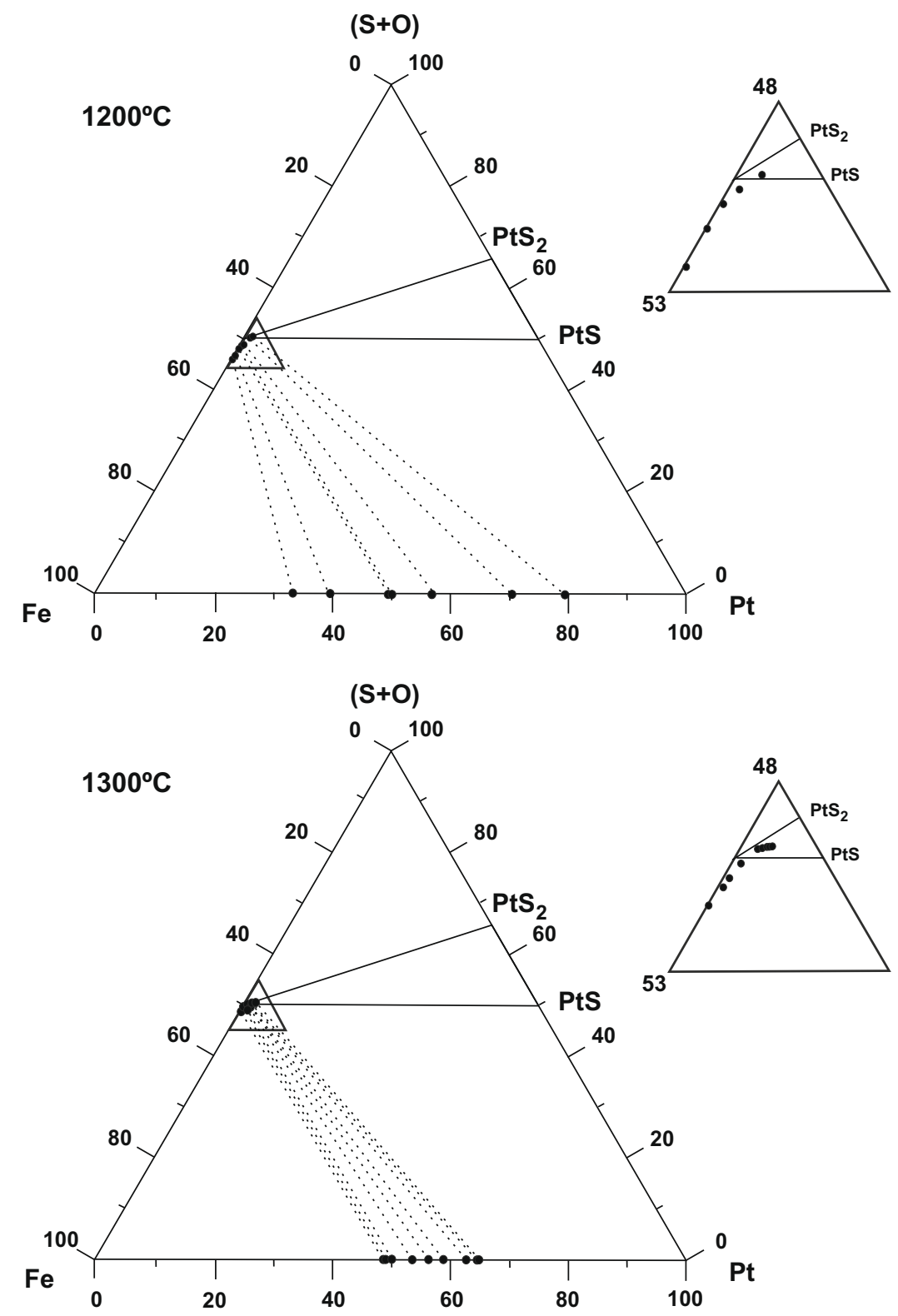

Fig. 5. Compositions of the matte plotted on the $\mathrm{Fe}-\mathrm{Pt}-(\mathrm{S}+\mathrm{O})$ ternary at $120{ }^{\circ} \mathrm{C}(\mathrm{A})$ and $1300{ }^{\circ} \mathrm{C}(\mathrm{B})$. Tie lines connect the equilibrium compositions of matte to the corresponding metal. Solid lines represent binary systems (e.g., FeS-PtS). In both cases, the more Pt-rich sulphides appear to follow a path along the FeS-PtS binary.

Subtracting Eq. (11) from Eq. (9) eliminates $a_{\mathrm{Pt}}$, to give:

$$
\begin{aligned}
\ln a_{\mathrm{PtO}}^{\text {sil }}-\ln a_{\mathrm{PtS}}^{\text {matte }}= & \frac{-\Delta G(10)+\Delta G(8)}{R T}+\frac{1}{2} \ln f \mathrm{O}_{2} \\
& +\frac{1}{2} \ln f \mathrm{~S}_{2}=\ln \left(\frac{X_{\mathrm{PtO}}^{\text {sil }} \gamma_{\mathrm{PtO}}^{\text {sil }}}{X_{\mathrm{PtS}}^{\text {matte }} \gamma_{\mathrm{PtS}}^{\text {matte }}}\right)
\end{aligned}
$$

The partition coefficient of Pt between matte and silicate melt is defined as:

$D_{\mathrm{Pt}}^{\mathrm{matte} / \text { sil }}=\ln \left(\frac{X_{\mathrm{Pt}}^{\text {matte }}}{X_{\mathrm{Pt}}^{\text {sil }}}\right)$

The effect of $\mathrm{Fe}$ on the solubility of $\mathrm{Pt}$ in matte can be eliminated by normalizing the solubility of PtS in the matte to unit activity of $\mathrm{Pt}$, using the appropriate values for $a_{\mathrm{Pt}}^{\text {matte }}$ from Table 3. An expression can then be derived to calculate the molar fraction of PtS in the matte (at unit activity) as a function of $f \mathrm{~S}_{2} a_{\mathrm{Pt}}^{\text {matte }}=1$.

$a_{\mathrm{Pt}}=1 \rightarrow\left(\frac{\Delta G(8)}{R T}-\ln \gamma_{\mathrm{PtS}}^{\text {matte }}\right)=\ln X_{\mathrm{PtS}}^{\mathrm{matte}}-\ln f \mathrm{~S}_{2}$

The equation above shows that if we plot activity normalised $\ln X_{\mathrm{PtS}}^{\mathrm{matte}}$ as a function of $\ln f \mathrm{~S}_{2}$, the $y$ intercept in this plot is $\frac{\Delta G(8)}{R T}-\ln \gamma_{\mathrm{PtS}}^{\text {matte }}$, which in this case equals -0.346 (Fig. 6). Moreover, the slope of the fit shown in Fig. 6 is $\sim 1 / 2$, which is the expected value when Pt dissolves in the matte as PtS. Therefore:

$\ln X_{\mathrm{PtS}}^{\mathrm{matte}}=0.47 \ln f \mathrm{~S}_{2}-0.346$ 
The solubility of Pt in a silicate melt at $1300^{\circ} \mathrm{C}$ can be described by the following equation Ertel et al. (1999):

$[\mathrm{Pt}]_{\mathrm{sil}}(\mathrm{ppb})=2100 f \mathrm{O}_{2}+10980 f \mathrm{O}_{2}^{1 / 2}$

From Eq. (16), the molar fraction of $\mathrm{PtO}$ in the silicate melt can be calculated as a function of $f \mathrm{O}_{2}$. This procedure gives $\frac{-\Delta G(10)}{R T}-\ln \gamma_{\mathrm{PtO}}^{\text {sil }}=-12.5$ and a slope of 0.5 , yielding:

$$
\begin{aligned}
\ln X_{\mathrm{PtO}}^{\mathrm{matte}} & =\left(\frac{-\Delta G(10)}{R T}-\ln \gamma_{\mathrm{PtO}}^{\mathrm{sil}}\right) \\
& =\ln X_{\mathrm{PtO}}^{\mathrm{sil}}-\frac{1}{2} \ln f \mathrm{O}_{2}=12.5 \Longleftrightarrow \ln X_{\mathrm{PtO}}^{\mathrm{sil}} \\
& =\frac{1}{2} \ln f \mathrm{O}_{2}-12.5
\end{aligned}
$$

Eqs. (15) and (17) can be combined to derive an equation for $D_{\mathrm{Pt}}^{\text {matte-sil }}$ as a function of both $f \mathrm{~S}_{2}$ and $f \mathrm{O}_{2}$ at unit activity of $\mathrm{Pt}$ :

$\ln D_{\mathrm{Pt}}^{\mathrm{matte} / \mathrm{sil}}=Q\left[0.47 \ln f \mathrm{~S}_{2}-\frac{1}{2} \ln f \mathrm{O}_{2}+12.15\right]$

where $Q$ is a constant to convert from $\frac{X_{\mathrm{Pt}}^{\text {matt }}}{X_{\mathrm{PtO}}^{\text {sil }}}$ into $\frac{X_{\mathrm{Pt}}^{\text {matte }}}{X_{\mathrm{Pt}}^{\text {sil }}}$.

\subsection{Extrapolation to natural systems: possible effects of $S$ and $\mathrm{Fe}$}

Eq. (18) is derived by combining our results on Pt solubility in $\mathrm{Fe}-\mathrm{S}-\mathrm{O}$ mattes with experiments on the solubility of $\mathrm{Pt}$ in simple-system silicate melts that lack both $\mathrm{Fe}$ and $\mathrm{S}$, two elements that have a strong geochemical affinity for Pt. This raises the question of whether these two elements, when present at their normal abundance in natural silicate melts, can affect the solubility of Pt sufficiently to invalidate our approach. The matter was considered by O'Neill et al. (1995), who concluded that the effects of neither Fe nor $\mathrm{S}$ would be large. As there have been several developments since 1995 that add weight to this conclusion, it is worth recapitulating the arguments here.

The thermodynamics of $\mathrm{S}$ dissolving as sulphide $\left(\mathrm{S}^{2-}\right)$ in silicate melts are well understood (see discussion in O'Neill

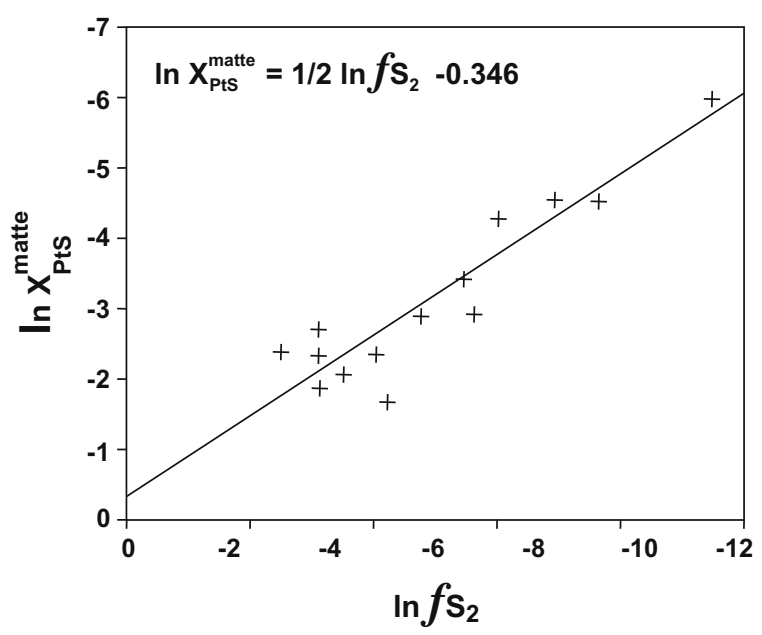

Fig. 6. Molar fraction of PtS in matte as a function of $f \mathrm{~S}_{2}$. and Mavrogenes (2002)). Under moderate to low oxygen fugacities, such as are appropriate for terrestrial basalts, $\mathrm{S}^{2-}$ dissolves by replacing $\mathrm{O}^{2-}$ on the anion sublattice, as shown experimentally by the variation of $\mathrm{S}$ solubility with $\left(f \mathrm{O}_{2} / f \mathrm{~S}_{2}\right)^{1 / 2}$, which relationship has been found valid for every composition of silicate melt investigated, both $\mathrm{Fe}$ containing and Fe-free (O'Neill and Mavrogenes, 2002). This relationship allows one to define a sulphide capacity $C_{\mathrm{S}}$ :

$\ln C_{\mathrm{S}}=\ln [\mathrm{S}]+1 / 2 \ln \left(f \mathrm{O}_{2} / f \mathrm{~S}_{2}\right)$

It has been shown experimentally that dependence of $C_{\mathrm{S}}$ on the composition of the melt is given by a relationship of the form:

$\ln C_{\mathrm{S}}=A_{0}+\sum_{\mathrm{M}} X_{\mathrm{M}} A_{\mathrm{M}}$

where $X_{\mathrm{M}}$ are the mole fractions of cations $\mathrm{M}$ in the silicate melt, and the coefficients $A_{\mathrm{M}}$ are related to the difference in the chemical potentials of the components $\mathrm{M}_{z} \mathrm{O}$ and $\mathrm{M}_{z} \mathrm{~S}$ in the silicate melt, which are in turn expected to be related, at least approximately, to the standard chemical potentials of the component oxide (or silicate) and sulphide, i.e.:

$A_{\mathrm{M}}=\left(\mu_{\mathrm{M}_{z} \mathrm{O}}-\mu_{\mathrm{M}_{z} \mathrm{~S}}\right) / R T+$ constant

(for a full derivation, see O'Neill and Mavrogenes, 2002, their Eqs. 6 to 19). This relationship shows qualitatively that the reason why Fe has such a strong influence on sulphide solubility in silicate melts is simply because $\mathrm{FeS}$ is more stable, thermodynamically, than FeO (O'Neill and Mavrogenes, 2002). Evans et al. (2008) have recently presented the experimental evidence for a similar relationship for some other chalcophile elements, namely $\mathrm{Mn}, \mathrm{Ni}$ and $\mathrm{Cu}$.

This experimentally tested thermodynamic model describing the effect of a cation $\mathrm{M}^{2 z+}$ in a silicate melt on $\mathrm{S}^{2-}$ solubility may be inverted rigorously (i.e., via the Gibbs-Duhem relationship) to calculate the influence of $\mathrm{S}^{2-}$ in the silicate melt on the activity coefficient of $\mathrm{M}_{z} \mathrm{O}$. Although we cannot use this approach to calculate the effect of $\mathrm{S}^{2-}$ on PGE components because the solubilities of PGE cations in silicate melts are not great enough to have a discernible influence on $\mathrm{S}$ solubilities, this approach nevertheless permits the question to be posed in a way that is amenable to quantitative reasoning. As pointed out in O'Neill et al. (1995 - see his Eqs. 13 and 14), the change in the activity coefficient of the component $\mathrm{Pt}_{x} \mathrm{O}$ in the silicate melt from substitution of $\mathrm{S}^{2-}$ for $\mathrm{O}^{2-}$ on the anion sublattice, relative to its activity in S-free melt of otherwise the same composition, is given by:

$\gamma_{\mathrm{Pt}_{x} \mathrm{O}}^{\text {melt, }+\mathrm{S}} / \gamma_{\mathrm{Pt}_{x} \mathrm{O}}^{\text {melt,no S }}=\exp \left\{\sum_{\mathrm{M}} X_{\mathrm{M}} X_{\mathrm{S}} \Delta \mu_{\mathrm{rec}}^{\mathrm{Pt}-\mathrm{M}} / R T\right\}$

where $\Delta \mu_{\mathrm{rec}}^{\mathrm{Pt}-\mathrm{M}}=\left(\mu_{\mathrm{Pt}_{x} \mathrm{O}}-\mu_{\mathrm{Pt}_{x} \mathrm{~S}}\right)-\left(\mu_{\mathrm{M}_{z} \mathrm{O}}-\mu_{\mathrm{M}_{x} \mathrm{~S}}\right), \sum_{\mathrm{M}} X_{\mathrm{M}}=1$, and $X_{\mathrm{S}}$ is the fraction of $\mathrm{S}^{2-}$ on the anion sublattice. For a silicate melt with $1000 \mathrm{ppm} S$ and $45 \mathrm{wt} \% \mathrm{O}$, $X_{\mathrm{S}}=0.001$. The question then boils down to what is a physically reasonable range in which values of $\Delta \mu_{\text {rec }}$ may fall? From the experimental $\mathrm{S}^{2-}$ solubility measurements summarized in Table 12 of O’Neill and Mavrogenes, 2002), 
we find that values of cations with the largest interactions with $\mathrm{S}$, namely $\mathrm{Fe}^{2+}$ and $\mathrm{Mn}^{2+}$, have values of $A_{\mathrm{Fe}}$ and $A_{\mathrm{Mn}}$ that are $\sim 20$ relative to non-chalcophile cations like $\mathrm{Ca}^{2+}$ and $\mathrm{Mg}^{2+}$ (i.e., $A_{\mathrm{Fe}}-A_{\mathrm{Ca}}, \approx 20$, etc. - see Table 12 in O'Neill and Mavrogenes, 2002). If we adopt this extreme value for $\mathrm{Pt}$ then we obtain $\gamma_{\mathrm{Pt}_{x} \mathrm{O}}^{\text {melt, }+\mathrm{S}} / \gamma_{\mathrm{Pt}_{x} \mathrm{O}}^{\text {melt,no } \mathrm{S}} \sim$ $\exp \{20 \times 0.001\}$, or $2 \%$, which is trivial given that even a factor of 10 change in $\gamma_{\mathrm{PtO}}^{\text {sil }}$ would not effect our arguments. Note that the thermochemical data for $\mathrm{PtO}_{2}$ and $\mathrm{PtS}_{2}$ (Barin, 1989) suggest values of $\Delta \mu_{\mathrm{rec}} / R T$ that are actually much less 20 , so even the $2 \%$ is likely to be overestimated.

In considering the possible effect of adding $\mathrm{Fe}$ to the simple-system silicate melts, we note first that there is nothing in the known chemical properties of PGE cations to expect any strong chemical interactions with $\mathrm{Fe}^{2+}$ (or $\mathrm{Fe}^{3+}$ ). The chemical properties of ionic substances are of course quite different from those of the elements from which they form, so there is no rational reason to expect that the large interactions between $\mathrm{Pt}$ and $\mathrm{Fe}$ in the metallic state should carry over into interactions between $\mathrm{Pt}^{x+}$ and $\mathrm{Fe}^{2+}$ in silicate melts. Ternary oxide compounds involving $\mathrm{Pt}^{x+}$ and $\mathrm{Fe}^{2+}$ are not known, so there is no reason to suppose that they might be unusually stable. Unlike for $\mathrm{S}$, there is now some experimental evidence for whether the presence of $\mathrm{Fe}$ in a silicate melt has a noticeable effect on the solubilities of some other PGEs, although Pt itself has not been studied explicitly. The issue was briefly reviewed by Borisov and Palme (2000), who quote direct evidence from the experimental study of Borisov et al. (1992), which demonstrated no difference in Ir solubilities between Fe-free melts and those containing up to $20 \mathrm{wt} \%$ "FeO" (total $\mathrm{Fe}$ as $\mathrm{FeO}$ ), whereas the study of Capobianco and Hervig (1996) found only a modest effect of $\mathrm{Fe}$ on Pd solubilities. Since then, Brenan et al. (2005) have studied the solubilities of Ir, Os and $\mathrm{Au}$ in high-FeO melts using laser-ablation ICP-MS as the analytical method, which of course has the advantage that nanonuggets would be detected if present. This study shows convincingly from nugget-free experiments that the solubilities of these elements are comparable to, or lower than, those in Fe-free compositions. The lower solubility of Ir found by Brenan et al. (2005) in their melts compared to O'Neill et al. (1995) in Fe-free anorthite-diopside eutectic melt is likely due to the much higher concentration of $\mathrm{CaO}$ in the latter, since basic oxide components like $\mathrm{CaO}$ are expected to enhance the solubility of high-valence cations like $\mathrm{Ir}^{3+}$ (e.g., O'Neill and Eggins, 2002). The lack of any effect of $\mathrm{FeO}$ on the solubility of $\mathrm{Re}$, another Highly Siderophile Element, has recently been documented by Mallmann and O’Neill (2007).

\section{DISCUSSION}

As discussed previously, the assumption that $D_{\mathrm{Pt}}^{\text {matte-sil }}$ lies appreciable below the value required for the magmatic hypothesis for Pt-rich ore deposits has lead to a number of ad hoc models to explain the origin of Pt-rich horizons in layered mafic intrusions (e.g., the Merensky Reef). However, our results as well as those from Pruseth and Palme (2004) have shown that $D_{\mathrm{Pt}}^{\text {mate-sil }}$ is larger than previous estimates by up to five orders of magnitude. The likely expla- nation is that the previous estimates were compromised by unrecognized nanonugget contamination, as they were performed under conditions that are in no significant way different from our experiments in which the equilibrium solubility of PGEs is completely obscured by nanonuggets. The nanonugget contamination is clearly revealed by laser-ablation ICP-MS analysis.

Our high calculated $D_{\mathrm{Pt}}^{\text {matte-sil }}$ values are in good agreement with calculated values for other PGE (Ru - Andrews and Brenan, 2002; Os - Brenan, 2008). Here we discuss some of the implications of very high $D_{\mathrm{Pt}}^{\text {matte-sil }}$, and consequent high enrichment of a matte in $\mathrm{Pt}$, to the enrichment models used to explain PGE-rich horizons associated with mafic intrusions.

\subsection{The relationship between the matte/silicate-melt mass ratio $(R)$, and $D_{\mathrm{Pt}}^{\text {mattesil }}$}

The difference between the $D_{\mathrm{Pt}}^{\text {matte-sil }}$ proposed in this study, and the much lower values proposed earlier by Helz and Rait (1988), Peach et al. (1990, 1994), Stone et al. (1990), Fleet et al. (1991, 1996), and Crocket et al. (1997), has implications for genetic models for Pt-rich horizons in large layered intrusions such as the Merensky Reef. If an element $i$ partitions between a sulphide-rich matte and a silicate melt of finite volume, it can be shown that the concentration of $i$ in the matte $\left(Y_{i}\right)$ is given by (Campbell and Naldrett, 1979):

$Y_{i}=X_{i}^{0} D_{i}(R+1) /\left(R+D_{i}\right)$

where $X_{i}^{0}$ is the original concentration of $i$ in the silicate melt, $R$ is the silicate-melt/sulphide-matte mass ratio, and $D_{i}$ the distribution coefficient of $i$ between sulphide-rich matte and silicate melt. Re-arranging the equation in terms of $R$ yields:

$R=\left[D_{i}\left(Y_{i} / X_{i}-1\right)\right] /\left[D_{i}-Y_{i} / X_{i}^{0}\right]$

where $Y_{i} / X_{i}^{0}$ is the apparent partition coefficient for the element $i$, called here the empirical partition coefficient $\left(D_{i}^{a}\right)$. Substituting $D_{i}^{a}$ into equation 24 yields:

$R=\left[D_{i}\left(D_{i}^{a}-1\right)\right] /\left[D_{i}-D_{i}^{a}\right]$

From Eq. (24), $R$ can be plotted as a function of $D_{i}$ for different values of $D_{i}^{a}$ (Fig. 7). Three observations can be made from Fig. 7:

(1) When $D_{i}>10 R, R \sim D_{i}^{a}$, and independent of $D_{i}$;

(2) When $R \leqslant D_{i} \leqslant 10 R, D_{i}^{a}$ depends on both $D_{i}$ and $R$;

(3) When $D_{i}<10 R, D_{i}^{a}$ depends on $D_{i}$ and is independent of $R$.

$D_{\mathrm{Pt}}^{a}$ for the Merensky Reef is between $10^{4}$ and $10^{5}$ (e.g., Campbell et al., 1983). When $D_{\mathrm{Pt}}^{\text {matte-sil }}$ is significantly smaller than $10^{5}$ (Helz and Rait, 1988; Peach et al., 1990, 1994; Stone et al., 1990; Fleet et al., 1991, 1996; Crocket et al., 1997), then $D_{\mathrm{Pt}}^{a}$ will depend on $D_{\mathrm{Pt}}^{\text {matte-sil }}$. On the other hand, if $D_{\mathrm{Pt}}^{\text {matte-sil }}$ is much larger than $D_{\mathrm{Pt}}^{a}$, (this study, Pruseth and Palme, 2004; Bezmen et al., 1991), then $D_{\mathrm{Pt}}^{a}$ equals $R$ and is independent of $D_{\mathrm{Pt}}^{\text {matte-sil }}$. 


\subsection{Should elemental PGE ratios in magmatic sulphides} reflect differences in their $D_{\mathrm{PGE}}^{\text {mattesil? }}$

It has been noted that the Pt/Pd of the Merensky Reef sulphides is equal to the ratio of the silicate melt it separated from (Davies and Tredoux, 1985). It has been argued that because $D_{\mathrm{Pt}}^{\text {matte-sil }}$ is unlikely to be equal to $D_{\mathrm{Pd}}^{\text {matte-sil }}$, the observation that $(\mathrm{Pt} / \mathrm{Pd})_{\text {matte }} \sim(\mathrm{Pt} / \mathrm{Pd})_{\text {sil }}$ is inconsistent with a magmatic hypothesis for the Merensky Reef sulphides (Ballhaus and Ryan, 1995). This argument is valid only if $D_{\mathrm{Pt}}^{\text {matte-sil }}$ and $D_{\mathrm{Pd}}^{\text {matte-sil }}<R$. However if $D_{\mathrm{Pt}}^{\text {matte-sil }}$ and $D_{\mathrm{Pd}}^{\text {matte-sil }}>>R$, it can be shown (see Eq. (27) below) that the $\mathrm{Pt} / \mathrm{Pd}$ in the matte is approximately equal to the $\mathrm{Pt} /$ $\mathrm{Pd}$ of the silicate melt it separated from.

Preliminary experiments where the solubility of $\mathrm{Pd}$ in mattes was investigated show that $\mathrm{Pd}$ is more compatible with the matte with respect to the metal phase than Pt. However, it was not possible to saturate a matte in Pd within the range of experimental conditions studied. For the purposes of this discussion a minimum $D_{\mathrm{Pd}}^{\text {metal-matte }}$ of 1 will be assumed. At QFM, $D_{\mathrm{Pd}}^{\text {matte-sil }}=3 \times 10^{8}$ (Borisov et al., 1994). By dividing $D_{\mathrm{Pd}}^{\text {matte-sil }}$ with $D_{\mathrm{Pd}}^{\text {metal-matte }}$, we obtained a $D_{\text {Pd }}^{\text {matte-sil }}>3 \times 10^{8}$.

Eq. (23) can be expressed as the ratio between the concentrations of $\mathrm{Pt}$ and $\mathrm{Pd}$ in the sulphide-rich matte $\left(Y_{\mathrm{Pd}} / Y_{\mathrm{Pt}}\right)$ :

$\frac{Y_{\mathrm{Pd}}}{Y_{\mathrm{Pt}}}=\frac{X_{\mathrm{Pd}}^{0} D_{\mathrm{Pd}}^{\text {matte-sil }}(R+1) /\left(R+D_{\mathrm{Pd}}^{\text {matte-sil }}\right)}{X_{\mathrm{Pt}}^{0} D_{\mathrm{Pt}}^{\text {matte-sil }}(R+1) /\left(R+D_{\mathrm{Pt}}^{\mathrm{matte}-\text { sil }}\right)}$

Assuming that $(R+1) \sim R$ and because $D>R$, then $(R+D) \sim D:$

$\frac{Y_{\mathrm{Pd}}}{Y_{\mathrm{Pt}}}=\frac{X_{\mathrm{Pd}}^{0} D_{\mathrm{Pd}}^{\text {matte-sil }} R / D_{\mathrm{Pd}}^{\text {matte-sil }}}{X_{\mathrm{Pt}}^{0} D_{\mathrm{Pt}}^{\text {matte-sil }} R / D_{P t}^{\text {matte-sil }}}$

Eq. (27) shows that if both $D_{\mathrm{Pt}}^{\text {matte-sil }}, D_{\mathrm{Pd}}^{\text {matte-sil }}>>R$, the $\mathrm{Pt} / \mathrm{Pd}$ ratio of the sulphide-rich matte is the same as in the parental silicate magmas and is independent of the difference between $D_{\mathrm{Pd}}^{\text {matte-sil }}$ and $D_{\mathrm{Pt}}^{\text {matte-sil }}$. As a consequence, if $D_{\mathrm{Pt}}^{\text {matte-sil }}$ and $D_{\mathrm{Pd}}^{\text {matte-sil }}$ are both greater than $10^{7}$, as this study suggests, the similarity between the $\mathrm{Pt} / \mathrm{Pd}$ ratio in the

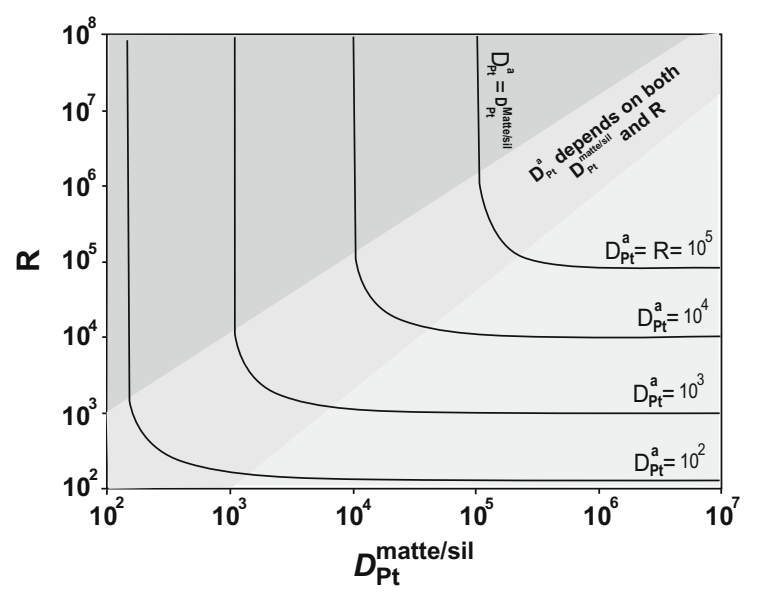

Fig. 7. Dependence of $D_{\mathrm{Pt}}^{a}$ on $R$ and $D_{\mathrm{Pt}}^{\text {matte-sil }}$. If $D_{\mathrm{Pt}}^{\text {matte-sil }}<R, D_{\mathrm{Pt}}^{a}$ depends on $D_{\mathrm{Pt}}^{\text {matte-sil }}$. If $D_{\mathrm{Pt}}^{\text {matte-sil }}>R, D_{\mathrm{Pt}}^{a}$ depends on $R$ and is independent of $D_{\mathrm{Pt}}^{\text {matte-sil }}$.
Merensky Reef and the silicate melt it crystallised from cannot be used to argue against an magmatic origin for PGErich horizons in layered intrusions, but rather provides strong evidence in support of this hypothesis.

\subsection{Matte/silicate-melt equilibrium as the primary cause for PGE enrichment in mafic layered intrusions}

Our high-temperature, supra-liquidus experiments show that the partition coefficients for Pt and the other PGE into sulphide mattes are well above the level required for the magmatic hypothesis to explain the PGE enrichment in Pt-rich horizons in layered intrusions. However, the highly chalcophile nature of Pt and other PGE in magmatic systems does not preclude the possibility that sulphides and PGE may be remobilized under subsolidus or near solidus conditions by deuteric or metasomatic fluids. Remobilization of sulphides by late stage fluids would undoubtedly modify the primary sulphide textures found in PGE-rich horizons in layered intrusions. The action of late fluids would be felt more strongly by phases with lower melting points, especially those that are soluble in hydrothermal fluids. In this respect sulphides are particularly vulnerable, and have been shown to be easily remobilized during low temperature metasomatism (e.g., Luguet et al., 2008). The remobilization of sulphides would leave behind the less mobile PGE, more refractory PGE-rich phases (platinum group minerals - PGM), giving the appearance that the fluids themselves were responsible for the initial enrichment (Godel et al., 2006, 2007). Even though fluids may locally remobilize the PGE, Wood (1987) in his experimental study of PGE solubilities in brine-rich fluids, argued that Pt and Pd solubilities in fluids are too low to be consistent with the observed enrichments found in layered mafic intrusions. Moreover, base metals such as, $\mathrm{Fe}, \mathrm{Cu}$ and $\mathrm{Ni}$ were shown to be over an order of magnitude more mobile than the PGE, which would cause an enrichment of base metals over the PGE. In PGE-rich horizons associated with mafic intrusions PGE tend to be greatly enriched relative to the base metals (see for example, Naldrett et al., 1987).

In light of the above discussion, it is possible to reconcile the textural evidence of metasomatism in mafic layered intrusions (e.g., Mathez, 1995), with the primary enrichment in $\mathrm{Pt}$, at supra-liquidus conditions, of a sulphide-rich matte relative to a silicate melt.

\section{ACKNOWLEDGMENTS}

We would like to thank Michael Shelley and Charles Magee, for providing invaluable assistance during ELA-Q-ICP-MS work; Ashley Norris for his assistance while using of the CAMECASX100 electron microprobe; Guilherme Mallmann, Chris Ballhaus and Ambre Luguet for their insightful reviews and comments. We thank Ed Ripley's editorial handling, and Ed Mathez, Alan Boudreau and an anonymous reviewer for their thorough reviews.

\section{REFERENCES}

Andrews D. R. A. and Brenan J. M. (2002) The solubility of ruthenium in sulfide liquid: implications for platinum group 
mineral stability and sulfide melt-silicate melt partitioning. Chem. Geol. 192, 163-181.

Ballhaus C. and Ryan C. G. (1995) Platinum-group elements in the Merensky reef. I. PGE in solid solution in base metal sulfides and the down temperature equilibration history of Merensky ores. Contrib. Mineral. Petrol. 122, 241-251.

Ballhaus C. G. and Stumpfl E. F. (1985) Occurrence and petrological significance of graphite in the upper critical zone, western Bushveld complex, South Africa. Earth Planet. Sci. Lett. 74, 58-68.

Ballhaus C. G. and Stumpfl E. F. (1986) Sulphide and platinum mineralization in the Merensky reef - evidence from hydrous silicates and fluid inclusions. Contrib. Mineral. Petrol. 122, 241251.

Barin I. (1989) Thermochemical Data of Pure Substances Part II. $\mathrm{VCH}$, Weinheim, Federal Republic of Germany, New York, NY, USA.

Barnes S. J. and Campbell I. H. (1988) Role of late magmatic fluids in Merensky type platinum deposits: a discussion. Geology 16, 488-491.

Barnes S. J. and Naldrett A. J. (1985) Geochemistry of the J-M (Howland) reef of the Stillwater complex, Minneapolis adit area. I. Sulfide chemistry and sulfide-olivine equilibrium. Econ. Geol. 80, 1251-1729.

Bezmen N. I., Asif M., Brügmann G. E., Romanenko I. M. and Naldrett A. J. (1994) Distribution of Pd, Rh, Ru, Ir and Au between sulfide and silicate metals. Geochim. Cosmochim. Acta 58, 1251-1260.

Bezmen N. I., Brügmann G. E., Asif M. and Naldrett A. J. (1991) Mechanism of concentration of platinum group elements: partitioning between silicate and sulfide melts. Int. Geol. Rev. 33, 784-792.

Borisov A. and Palme H. (1997) Experimental determination of the solubility of platinum in silicate melts. Geochim. Cosmochim. Acta 61, 4349-4357.

Borisov A. and Palme H. (2000) Solubilities of noble metals in Fecontaining silicate melts as derived from experiments in Fe-free systems. Am. Mineral. 85, 1665-1673.

Borisov A., Palme H. and Spettel B. (1994) Solubility of palladium in silicate melts: implications for core formation in the earth. Geochim. Cosmochim. Acta 58, 705-716.

Borisov A., et al. (1992). The origin of highly siderophile elements in the upper mantle of the Earth: an experimental approach. In Proc. Lunar Planet. Sci. Conf., vol. XXIII, pp. 139-140.

Boudreau A. E. and McCallum I. S. (1992) Concentration of platinum-group elements by magmatic fluids in layered intrusions. Econ. Geol. 87, 1830-1848.

Boudreau A. E. and Meurer W. P. (1999) Chromatographic separation of the platinum-group elements, gold, base metals and sulphur during degassing of a compacting and solidifying igneous crystal pile. Contrib. Mineral. Petrol. 134, 174-185.

Brenan J. M., McDonough W. F. and Ash R. (2005) An experimental study of the solubility and partitioning of iridium, osmium and gold between olivine and silicate melt. Earth Planet. Sci. Lett. 237, 855-872.

Brenan M. J. (2008) Re-Os fractionation by sulfide melt silicate melt partitioning: a new spin. Chem. Geol. 248, 140-165.

Campbell I. H. and Barnes S. J. (1984) A model for the geochemistry of the platinum-group elements in magmatic sulfide deposits. Can. Mineral. 22, 151-160.

Campbell I. H. and Naldrett A. J. (1979) The influence of silicate:sulfide ratios on the geochemistry of magmatic sulfides. Econ. Geol. 74, 1503-1506.

Campbell I. H., Naldrett A. J. and Barnes S. J. (1983) A model for the origin of the platinum rich sulfide horizons in the Bushveld and Stillwater complexes. J. Petrol. 24, 133-165.
Capobianco C. and Hervig R. (1996) Solubility of Ru and Pd in silicate melts: the effect of melt composition. In Proc. Lunar Planet. Sci. Conf., vol. XXVII, p. 197.

Chase M. W. (1998) NIST-JANAF Thermodynamic Tables. National Institute of Standards and Technology, Washington, DC, USA.

Crocket J. H., Fleet M. E. and Stone W. E. (1997) Implications of composition for experimental partitioning of platinum-group elements and gold between sulfide liquid and basalt melt: the significance of nickel content. Geochim. Cosmochim. Acta 61, 4139-4149.

Davies G. and Tredoux M. (1985) The platinum group element and gold content of marginal rocks and sills of the bushveld complex. Econ. Geol. 80, 838-848.

Ertel W., Dingwell D. B. and Sylvester P. J. (2008) Siderophile elements in silicate melts - a review of the mechanically assisted equilibration technique and the nanonugget issue. Chem. Geol. 248, 119-139.

Ertel W., O’Neill H. S. C., Sylvester P. J. and Dingwell D. B. (1999) Solubilities of $\mathrm{Pt}$ and $\mathrm{Rh}$ in a haplobasaltic silicate melt at $1300{ }^{\circ}$ C. Geochim. Cosmochim. Acta 63, 2439-2449.

Evans K., O’Neill H. and Mavrogenes J. (2008) Sulphur solubility and sulphide immiscibility in silicate melts as a function of the concentration of manganese, nickel, tungsten and copper at $1 \mathrm{~atm}$ and $1400^{\circ} \mathrm{C}$. Chem. Geol. 255, 236-249.

Fleet M. E., Crocket J. H., Menghua L. and Stone W. E. (1999) Laboratory partitioning of platinum-group elements (PGE) and gold with applications to magmatic sulfide-PGE deposits. Lithos 47, 127-142.

Fleet M. E., Crocket J. H. and Stone W. E. (1996) Partitioning of platinum-group elements ( $\mathrm{Os}, \mathrm{Ir}, \mathrm{Ru}, \mathrm{Pt}, \mathrm{Pd})$ and gold between sulfide liquid and basalt melt. Geochim. Cosmochim. Acta $\mathbf{6 0}$, 2397-2412.

Fleet M. E. and Stone W. E. (1991) Partitioning of platinum group elements in the $\mathrm{Fe}-\mathrm{Ni}-\mathrm{S}$ system and their fractionation in nature. Geochim. Cosmochim. Acta 55, 245-253.

Fleet M. E., Stone W. E. and Crocket J. H. (1991) Partitioning of palladium, iridium, platinum and gold between sulfide liquid and basalt melt: effects of melt composition, concentration and oxygen fugacity. Geochim. Cosmochim. Acta 55, 2545-2554.

Fonseca R. O. C., Campbell I. H., O'Neill H. S. C. and Fitzgerald J. D. (2008) Oxygen solubility and speciation in sulphide-rich mattes. Geochim. Cosmochim. Acta 72(1), 2619-2635.

Fonseca R. O. C., Mallmann G., O’Neill H. S. C. and Campbell I. H. (2007) How chalcophile is rhenium? An experimental study of the solubility of Re in sulphide mattes. Earth Planet. Sci. Lett. 260, 537-548.

Fortenfant S. S., Günther D., Dingwell D. B. and Rubie D. C. (2003) Temperature dependence of $\mathrm{Pt}$ and $\mathrm{Rh}$ solubilities in a haplobasaltic melt. Geochim. Cosmochim. Acta 67, 123-131.

Godel B., Barnes S.-J. and Maier W. D. (2007) Platinum-group elements in sulphide minerals, platinum-group minerals and the whole rocks of the Merensky Reef (Bushveld Complex, South Africa): implications for the formation of the reef. Chem. Geol. 48, 1569-1604.

Godel B., Barnes S. J. and Maier W. F. (2006) 3D distribution of sulphide minerals in the Merensky Reef (Bushveld complex, South Africa) and the J-M Reef (Stillwater complex, USA) and their relationship to microstructures using X-ray computed tomography. J. Petrol. 47, 1853-1872.

Gudmundsson G. and Holloway J. R. (1993) Activity-composition relationships in the system $\mathrm{Fe}-\mathrm{Pt}$ at 1300 and $1400^{\circ} \mathrm{C}$ and at $1 \mathrm{~atm}$ and $20 \mathrm{kbar}$. Am. Mineral. 78, 178-186.

Helz R. T. and Rait N. (1988) Behavior of Pt and Pd in Kilauea Iki lava lake. V.M. Goldschmidt Conference Abstract, Baltimore, p. 47. 
Keays R. R. and Campbell I. H. (1981) Precious metals in the jimberlana intrusion, western Australia: implications for the genesis of platiniferous ores in layered intrusions. Econ. Geol. 76, 1118-1141.

Kress V. (1997) Thermochemistry of sulfide liqfluids. I. The system O-S-Fe at 1 bar. Contrib. Mineral. Petrol. 127, 176-186.

Kress V. (2007) Thermochemistry of sulfide liqfluids. III. Nibearing liquids at 1 bar. Contrib. Mineral. Petrol. 154, 191-204.

Larocque A. C. L., Stimac J. A., Keith J. D. and Huminicki M. A. E. (2000) Evidence for open-system behavior in immiscible $\mathrm{Fe}-$ $\mathrm{S}-\mathrm{O}$ liquids in silicate magmas: implications for contributions of metals and sulfur to ore-forming fluids. Can. Mineral. 38, $1233-1249$.

Luguet A., Lorand J., Alard O. and Cottin J. (2004) A multitechnique study of platinum group element systematic in some Ligurian ophiolitic peridotites, Italy. Chem. Geol. 208, 175-194.

Luguet A., Pearson D. G., Nowell G. M., Dreher S. T., Coggon J. A., Spetsius Z. V. and Parman S. W. (2008) Enriched Pt-Re-Os isotope systematics in plume lavas explained by metasomatic sulfides. Science 319, 453-456.

Majzlan J., Makovicky M., Makovicky E. and Rose-Hansen J. (2002) The system Fe-Pt-S at $1100^{\circ} \mathrm{C}$. Can. Mineral. 40, 509517.

Mallmann G. and O'Neill H. S. C. (2007) The effect of oxygen fugacity on the partitioning of rhenium between crystals and silicate melt during mantle melting. Geochim. Cosmochim. Acta 71, 2837-2857.

Mathez E. (1995) Magmatic metasomatism and formation of the Merensky reef, Bushveld Complex. Contrib. Mineral. Petrol. 119, 277-286.

Meurer W. P. and Boudreau A. E. (1998) Concentration of platinum-group elements by magmatic fluids in layered intrusions. J. Geol. 106, 281-292.

Meurer W. P., Klaber S. and Boudreau A. E. (1997) Discordant bodies from olivine-bearing zones III and IV of the Stillwater complex, Montana - evidence for postcumulus fluid migration and reaction in layered intrusions. Contrib. Mineral. Petrol. 130, 81-92.

Moretti R. and Baker D. R. (2008) Modeling the interplay of $f \mathrm{O}_{2}$ and $f \mathrm{~S}_{2}$ along the FeS-silicate melt equilibrium. Chem. Geol. 256, 285-297.
Naldrett A. J., Cameron G., Gruenewaldt G. V. and Sharpe M. R. (1987) The formation of stratiform PGE deposits in layered intrusions. In Origin of Igneous Layering (ed. I. Parsons). Reidel, Dordrecht, pp. 313-397.

Okamoto H. (2002) Phase Diagrams of Binary Iron Alloys. The materials information Society, Ohio, USA.

O'Neill H. S. C., Dingwell D. B., Borisov A., Spettel B. and Palme H. (1995) Experimental petrochemistry of some highly siderophile elements at high temperatures, and some implications for core formation and the mantles early history. Chem. Geol. 120, 255-273.

O'Neill H. S. C. and Eggins S. M. (2002) The effect of melt composition on trace element partitioning: an experimental investigation on the activity coefficients of $\mathrm{FeO}, \mathrm{NiO}, \mathrm{CoO}$, $\mathrm{MoO}_{2}$ and $\mathrm{MoO}_{3}$. Chem. Geol. 186, 151-181.

O'Neill H. S. C. and Mavrogenes J. A. (2002) The sulphide capacity and the sulphur content at sulfide saturation of silicate melts at $1400{ }^{\circ} \mathrm{C}$ and 1 bar. J. Petrol. 43, 1049-1087.

Peach C. L., Mathez E. A. and Keays R. R. (1990) Sulfide meltsilicate melt distribution coefficients for noble metals and other chacophile elements as deduced from MORB: implications for partial melting. Geochim. Cosmochim. Acta 54, 3379-3389.

Peach C. L., Mathez E. A., Keays R. R. and Reeves S. J. (1994) Experimentally determined sulfide melt-silicate melt partition coefficients for iridium and palladium. Chem. Geol. 117, 361377.

Pruseth K. L. and Palme H. (2004) The solubility of Pt in liquid Fesulfides. Chem. Geol. 208, 233-245.

Raghavan V. (1988) Phase Diagrams of Ternary Iron Alloys Pt. 2. Indian Institute of Technology, Delhi, India.

Stone W. E., Crocket J. H. and Fleet M. E. (1990) Partitioning of palladium, iridium, platinum and gold between sulfide liquid and basalt melt. Geochim. Cosmochim. Acta 54, 2341-2344.

Wood S. (1987) Thermodynamic calculations of the volatility of the platinum group elements (PGE): the PGE content of fluids at magmatic temperatures. Geochim. Cosmochim. Acta 51, 30413050 .

Associate editor: Edward M. Ripley 